\title{
Remote Sensing of Coral Reefs for Monitoring and Management: A Review
}

\author{
John D. Hedley ${ }^{1, *}$, Chris M. Roelfsema ${ }^{2}$, Iliana Chollett ${ }^{3}$, Alastair R. Harborne ${ }^{4,5}$, \\ Scott F. Heron ${ }^{6,7,8}$, Scarla J. Weeks ${ }^{9}$, William J. Skirving ${ }^{6,7}$, Alan E. Strong ${ }^{6,7}$, C. Mark Eakin ${ }^{6}$, \\ Tyler R. L. Christensen ${ }^{6,7}$, Victor Ticzon ${ }^{10}$, Sonia Bejarano ${ }^{11}$ and Peter J. Mumby ${ }^{4}$ \\ 1 Environmental Computer Science Ltd., Raymond Penny House, Tiverton, Devon EX16 6LR, UK \\ 2 Remote Sensing Research Centre, School of Geography Planning and Environmental Management, \\ University of Queensland, Brisbane, QLD 4072, Australia; c.roelfsema@uq.edu.au \\ 3 Smithsonian Marine Station, Smithsonian Institution, Fort Pierce, FL 34949, USA; iliana.chollett@gmail.com \\ 4 Marine Spatial Ecology Laboratory and Australian Research Council Centre of Excellence for Coral Reef \\ Studies, School of Biological Sciences, University of Queensland, Brisbane, QLD 4072, Australia; \\ a.harborne@uq.edu.au (A.R.H.); p.j.mumby@uq.edu.au (P.J.M.) \\ 5 Department of Biological Sciences, Florida International University, 3000 Northeast 151 Street, \\ North Miami, FL 33181, USA \\ 6 Coral Reef Watch, U.S. National Oceanic and Atmospheric Administration, College Park, MD 20740, USA; \\ scott.heron@noaa.gov (S.F.H.); william.skirving@noaa.gov (W.J.S.); alan.e.strong@noaa.gov (A.E.S.); \\ mark.eakin@noaa.gov (C.M.E.); trlchristensen@gmail.com (T.R.L.C.) \\ 7 Global Science and Technology, Inc., Greenbelt, MD 20770, USA \\ 8 Marine Geophysical Laboratory, Physics Department, College of Science, Technology and Engineering, \\ James Cook University, Townsville, QLD 4811, Australia \\ 9 Biophysical Oceanography Group, Remote Sensing Research Centre, School of Geography, Planning and \\ Environmental Management, University of Queensland, Brisbane, QLD 4072, Australia; s.weeks@uq.edu.au \\ 10 Institute of Biological Sciences, College of Arts and Sciences, University of the Philippines-Los Baños \\ College, Laguna, 4031, Philippines; vsticzon@up.edu.ph \\ 11 Leibniz Center for Tropical Marine Ecology, Fahrenheitstrasse 6, Bremen 28359, Germany; \\ sonia.bejarano@leibniz-zmt.de \\ * Correspondance: j.d.hedley@envirocs.com; Tel.: +44-780-315-0032
}

Academic Editors: Richard Gloaguen and Prasad S. Thenkabail

Received: 19 October 2015; Accepted: 21 December 2015; Published: 6 February 2016

\begin{abstract}
Coral reefs are in decline worldwide and monitoring activities are important for assessing the impact of disturbance on reefs and tracking subsequent recovery or decline. Monitoring by field surveys provides accurate data but at highly localised scales and so is not cost-effective for reef scale monitoring at frequent time points. Remote sensing from satellites is an alternative and complementary approach. While remote sensing cannot provide the level of detail and accuracy at a single point than a field survey, the statistical power for inferring large scale patterns benefits in having complete areal coverage. This review considers the state of the art of coral reef remote sensing for the diverse range of objectives relevant for management, ranging from the composition of the reef: physical extent, benthic cover, bathymetry, rugosity; to environmental parameters: sea surface temperature, exposure, light, carbonate chemistry. In addition to updating previous reviews, here we also consider the capability to go beyond basic maps of habitats or environmental variables, to discuss concepts highly relevant to stakeholders, policy makers and public communication: such as biodiversity, environmental threat and ecosystem services. A clear conclusion of the review is that advances in both sensor technology and processing algorithms continue to drive forward remote sensing capability for coral reef mapping, particularly with respect to spatial resolution of maps, and synthesis across multiple data products. Both trends can be expected to continue.
\end{abstract}


Keywords: coral reef; management; monitoring; habitat; physical environment; review

\section{Introduction}

Coral reefs are in decline worldwide [1-4]. By 2011 19\% of reefs had been lost and 75\% were threatened [5,6]. This decline is a result of the combined effects of natural and anthropogenic threats operating at both regional and global scales [5,6]. At the regional scale, human activities such as coastal development, overexploitation and destructive fishing practices, pollution and runoff [6,7] have triggered coral reef deterioration. Rising atmospheric carbon dioxide, through global warming and ocean acidification, has already contributed to the degradation of these ecosystems and can exacerbate regional stressors $[8,9]$.

There is increasing awareness of the magnitude of threats facing coral reef ecosystems [6], and monitoring activities have become important for assessing the impact of disturbance on reefs and tracking subsequent recovery or decline. Several coral reef monitoring programs based on field surveys have been developed to assess the status of coral reefs worldwide. These range from global initiatives such as Reef Check (http://www.reefcheck.org) [10] and the CoralWatch project (http:/ / www.coralwatch.org), to regional initiatives including Coral Reef Degradation in the Indian Ocean (CORDIO) (http:/ / cordioea.net) [11], the Caribbean Coastal Marine Productivity Program (CARICOMP) [12] and the Atlantic and Gulf Rapid Reef Assessment (AGRRA) Program (http://www.agrra.org). Data from these programs supports efforts such as the Global Coral Reef Monitoring Network, which from 1998-2008 provided biennial reports on the world status of coral reefs [5,13-16]. In addition, long term trends have been elucidated by various meta-analyses that combine disparate data sources $[2,17,18]$. However, in situ coral reef monitoring has several caveats that restrict its use and the relevance of its outcomes. These are (1) cost-related: detailed, continuous monitoring of coral reefs by field survey is expensive and substantial reef areas are located in developing countries with limited resources; (2) scale-related: reefs are highly heterogeneous systems $[19,20]$ therefore even with sufficient resources monitoring programs provide scattered information in time and space, with some areas being more intensively sampled than others and less easily accessible areas are typically under-sampled; and (3) focus-related: most field monitoring programs are focused on the state variables describing some of the biological components of the reef system and are not linked explicitly to the identification of stressors or processes. Monitoring schemes enable documentation of the decline or recovery of certain components of the system, but rarely permit an investigation of the drivers of these changes, thereby creating an obstacle in translating scientific information into decision making and mitigatory action [21,22].

The issue of inconsistency and lack of coordinated focus between localised surveys has been identified [18] and efforts are underway towards defining global protocols for coral reef monitoring, data collection and archiving [23]. The issue of scale remains a challenge for interpretation of field survey data. Even the most comprehensive and well-conducted survey programs, such as that of the Australian Institute of Marine Science Long-Term Monitoring Program [24] struggle with the challenge that, for example, only a tiny fractional percentage of the 344,000 square kilometre area of the Great Barrier Reef can be surveyed. The next generation of field surveys is likely to be autonomous, towed or diver-operated camera surveys, such as the XL Catlin Seaview Survey [25] combined with automatic image analysis [26]. The XL Catlin Seaview Survey is currently diver operated but is researching ways to convert to autonomous systems, including low-altitude unmanned aerial vehicles. These approaches may increase the scales achievable by field surveys and improve the capability for standardisation. Nevertheless, given the physical scale and distribution of reefs on the planet, survey techniques requiring human presence at the site will for economic reasons always be limited in scope or temporal repeatability. 
Using remote sensing within a monitoring program potentially addresses many of the caveats highlighted above. Remote sensing covers many technologies, from satellites to airborne sensors, unmanned aerial systems, boat-based systems and autonomous underwater vehicles. In comparison to the sampling of physical areas achievable by field survey, habitat mapping and environmental stress assessment by remote sensing, especially by satellites, is highly cost-effective $[27,28]$. While mapping reef composition from a satellite inherently cannot provide the level of accuracy and detail than could a field survey at that same point, the statistical power for inferring large scale patterns benefits in having complete areal coverage. Estimations of the statistical power of airborne data for mapping live coral by Mumby et al. [29] implied that $20 \mathrm{~s}$ of airborne acquisition time were equal to 6 days of field survey. Satellite data provides less detail than airborne data but is potentially even more cost-effective: acquisition costs can be zero, so data processing becomes the main expenditure.

Remote sensing enables the simultaneous study of extensive reef areas for the assessment of spatial patterns and can provide a high frequency of observation for the assessment of temporal patterns [30]. Environmental monitoring programs targeted to reef scientists and managers use satellite data to provide information on the environment around reef systems (e.g., the U.S. National Oceanic and Atmospheric Administration's Coral Reef Watch program, ReefTemp, the IMaRS observing system). Most base their monitoring activities on sea surface temperature analyses, due to the large impact this stress agent has had on coral reef systems during recent decades [8]. Products for ocean colour, light, winds and ocean acidification are also available. Combining remote sensing datasets of environmental factors with reef mapping potentially allows characterising physical and biological linkages at large scales. Putative stressors can be evaluated in conjunction with biological responses for the establishment of causative links (e.g., [31]). While the use of historical data allows retrospective analyses, near-real-time information enables the assessment of present stress conditions, thereby raising awareness of the potential changes to the ecosystem before they occur [32]. Furthermore, the use of remote sensing data to initialise and track predictive models enables scientists to forecast the future conditions of the reef and to take appropriate measures to minimise damage.

In this review we evaluate the current state of the art of satellite remote sensing capabilities with the potential to support the monitoring and management of coral reef ecosystems. Airborne systems and boat-based sonar are also relevant and will be mentioned. The detail that hyperspectral airborne systems provide can be indicative of potential future satellite capability. Use of boat-based sonar is well established and frequently associated or combined with satellite data acquisitions. The aim of the review is to provide an in-depth reference to reef researchers and managers that complements and updates previously published reviews from five and ten years ago [33,34]. In addition to the scope of those previous reviews, here we also consider the capability to go beyond basic maps of habitats or environmental variables, to discuss concepts highly relevant to stakeholders, policy makers and public communication: such as biodiversity, environmental threat and ecosystem services. This kind of work is key to the on-going synergy between remote sensing, reef ecology and conservation.

The following has been divided into three sections: the first discusses remote sensing technologies for mapping or quantifying reef extent, composition and structure; the second section discusses environmental monitoring; technologies for evaluating the physical environment on or near reef locations; and the final section discusses combining and converting these basic products into key parameters of reef ecology and conservation.

\section{Habitat and Reef Structure Mapping}

This section discusses methods that provide information on the coral reefs themselves: extent; reef type; geomorphic zonation; benthic and substrate community composition; specific cover types; quantitative cover; and three dimensional reef structure (Figure $1([35,36])$, Table 1). This kind of information is essential for management; maps of resources and the location of critical habitats and biotopes are the baseline for a management plan, especially when using spatial analysis tools such as Marxan [37] (see Section 4). Habitat mapping is often created with optical passive remote sensing, 
integrated with field data for calibration and validation. Many different data sources and analysis techniques have been applied: this section reviews those efforts to summarise what has been achieved, the current state-of-the art, and the fundamental limitations. The first sub-section presents an overview of available image data and how this relates to mapping objectives. The following sub-sections give details on specific objectives such as benthic mapping, bathymetry and terrestrial factors associated with reefs.

\section{Spatial and Temporal Resolution for Selected Parameters}

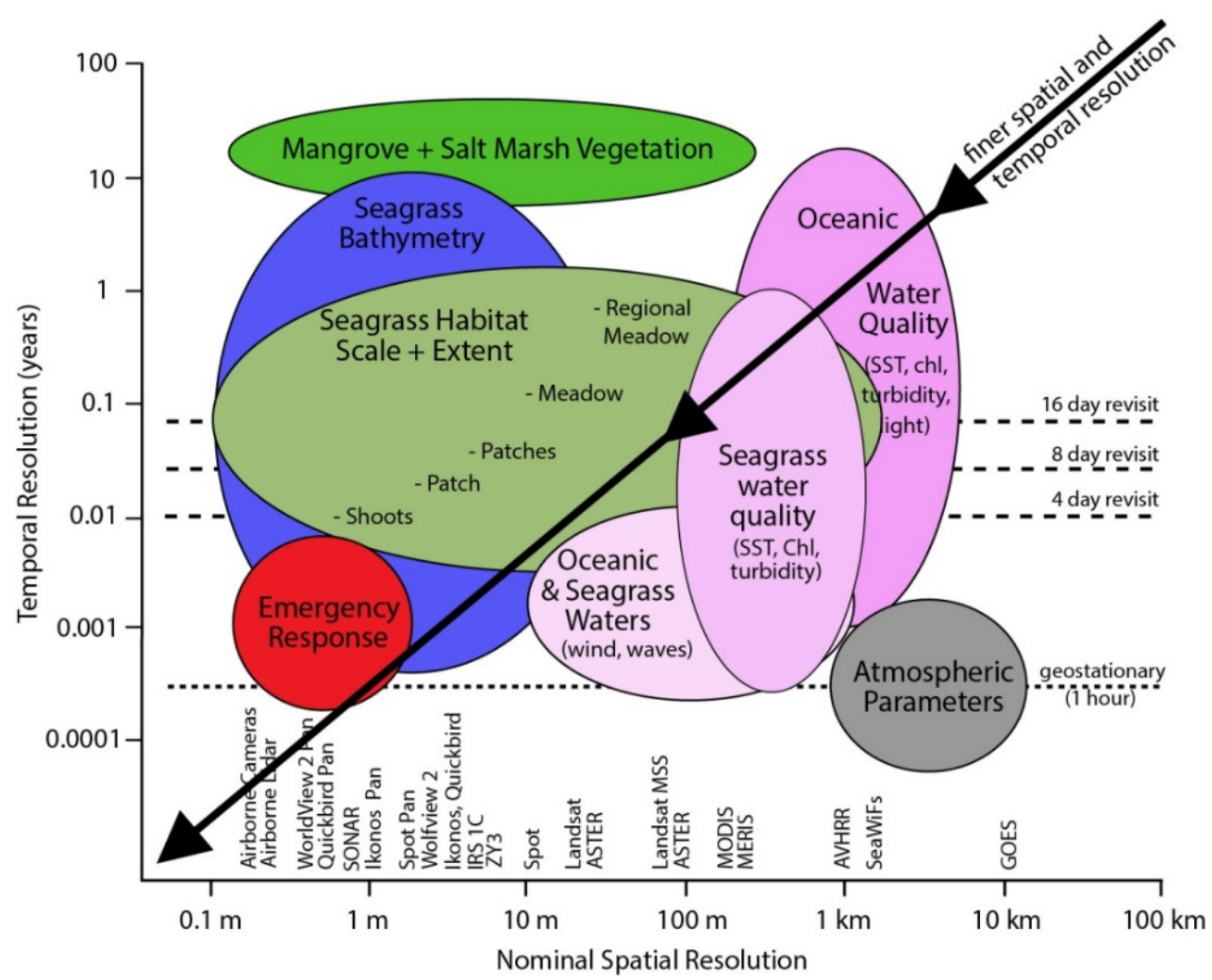

Figure 1. Spatial and temporal scales of coral reef mapping and monitoring application in relation to the pixel size and temporal frequency of commercially available airborne and satellite image data (source $[35,36])$.

\subsection{Technologies, Achievable Level of Detail and Limitations}

Remote sensing imagery in the visible wavelengths is commonly used to perform mapping on coral reefs, utilising multispectral data (less than 10 broad wavelength bands) or hyperspectral (more than 10 narrow bands), acquired by airborne or satellite based sensors [34]. The terms "multispectral" and "hyperspectral" are not precisely defined and the definition is further complicated for benthic mapping which can only make use of the visible (i.e., water penetrating) wavelengths, approx. 400 to $740 \mathrm{~nm}$. So while "hyperspectral" typically means an instrument with in excess of 100 bands often only a subset of these will be useable. In addition to wavelength characteristics imagery can be further divided by spatial resolution into very high (pixels less than $1 \mathrm{~m}$ ), high (1-10 m), moderate $(10-100 \mathrm{~m})$ and low (100-1000 m). Higher spatial resolution imagery typically covers a small spatial extent, e.g., less than $100 \mathrm{~km}^{2}$ as opposed to $10,000 \mathrm{~s}$ of $\mathrm{km}^{2}$ covered by moderate and low spatial resolutions (Figure 2).

The spatial and spectral resolutions both contribute to what can be discriminated in a mapping objective, so that dependent on the instrument used, various levels of "descriptive resolution" [38] can be derived, from geomorphic zones (e.g., fore reef, reef crest) [39] to benthic community cover 
(e.g., coral on reef matrix, algae and coral on rubble) [40-42] and in some cases benthic type (e.g., branching coral, brown algae) $[29,43,44]$ (Figure 1). The level of detail achievable is typically in proportion to data cost and processing effort: geomorphic mapping is possible with freely available Landsat data and off the shelf software, whereas the highest level of habitat or benthic type mapping requires airborne hyperspectral data and for some techniques custom processing.

Table 1. Available remote sensing technologies for coral reef mapping.

\begin{tabular}{llll}
\hline Objective and Sensor & Feasibility & Considerations & Caveats and Limitations \\
\hline Reef Extent & Routinely possible & $\begin{array}{l}\text { Spatial heterogeneity at } \\
\text { the location determines } \\
\text { the spatial resolution of } \\
\text { the sensor to use } \\
\text { airborne sensors }\end{array}$ & \\
\hline Rugosity & Routinely possible & $\begin{array}{l}\text { Depth, turbidity and } \\
\text { spatial heterogeneity at } \\
\text { the location determine } \\
\text { the acoustic method } \\
\text { (laser, sound) to use }\end{array}$ & $\begin{array}{l}\text { Maps have to be generated by } \\
\text { interpolating between tracks, } \\
\text { producing inaccurate results if } \\
\text { there are large gaps within } \\
\text { the dataset }\end{array}$ \\
\hline
\end{tabular}

Coral vs. macroalgae

\begin{tabular}{|c|c|c|c|}
\hline $\begin{array}{l}\text { Hyperspectral } \\
\text { airborne sensors }\end{array}$ & $\begin{array}{l}\text { Demonstrated in } \\
\text { limited cases only }\end{array}$ & $\begin{array}{l}\text { Water column } \\
\text { attenuation, presence of } \\
\text { spectrally similar } \\
\text { components and spatial } \\
\text { heterogeneity at the } \\
\text { location determine the } \\
\text { feasibility of the method }\end{array}$ & $\begin{array}{l}\text { Spectral mixing makes the } \\
\text { quantification of cover not } \\
\text { routinely possible at this time }\end{array}$ \\
\hline \multicolumn{4}{|l|}{ Coral mortality } \\
\hline $\begin{array}{l}\text { Hyperspectral } \\
\text { airborne sensors }\end{array}$ & $\begin{array}{l}\text { Demonstrated in } \\
\text { limited cases only }\end{array}$ & $\begin{array}{l}\text { Water column } \\
\text { attenuation and spatial } \\
\text { heterogeneity at the } \\
\text { location determine the } \\
\text { feasibility of the method. }\end{array}$ & $\begin{array}{l}\text { Only mass mortalities can } \\
\text { be detected. }\end{array}$ \\
\hline \multicolumn{4}{|l|}{ Coral bleaching } \\
\hline $\begin{array}{l}\text { Multispectral and } \\
\text { hyperspectral airborne } \\
\text { and satellite sensors }\end{array}$ & $\begin{array}{l}\text { Demonstrated in } \\
\text { theory and limited } \\
\text { cases only }\end{array}$ & $\begin{array}{l}\text { Water column } \\
\text { attenuation and spatial } \\
\text { heterogeneity at the } \\
\text { location determine the } \\
\text { feasibility of the method. } \\
\text { Spectral confusion with } \\
\text { sand should be avoided } \\
\text { by comparison with a } \\
\text { previous image for the } \\
\text { same location }\end{array}$ & $\begin{array}{l}\text { Spectral discrimination of } \\
\text { various bleaching intensities is } \\
\text { not feasible. Unless mass } \\
\text { bleaching has occurred in a } \\
\text { location, bleaching } \\
\text { assessments using satellite } \\
\text { imagery are not feasible }\end{array}$ \\
\hline \multicolumn{4}{|l|}{ Bathymetry } \\
\hline $\begin{array}{l}\text { Hyperspectral airborne } \\
\text { and high resolution } \\
\text { satellite sensors, acoustic } \\
\text { and LIDAR. }\end{array}$ & Routinely possible & $\begin{array}{l}\text { Processing optical } \\
\text { imagery may be quite } \\
\text { involved for the } \\
\text { best methods }\end{array}$ & $\begin{array}{l}\text { Accuracy from optical data is } \\
\text { limited by depth and water } \\
\text { turbidity. Acoustic methods } \\
\text { require interpolation } \\
\text { between tracks. }\end{array}$ \\
\hline
\end{tabular}




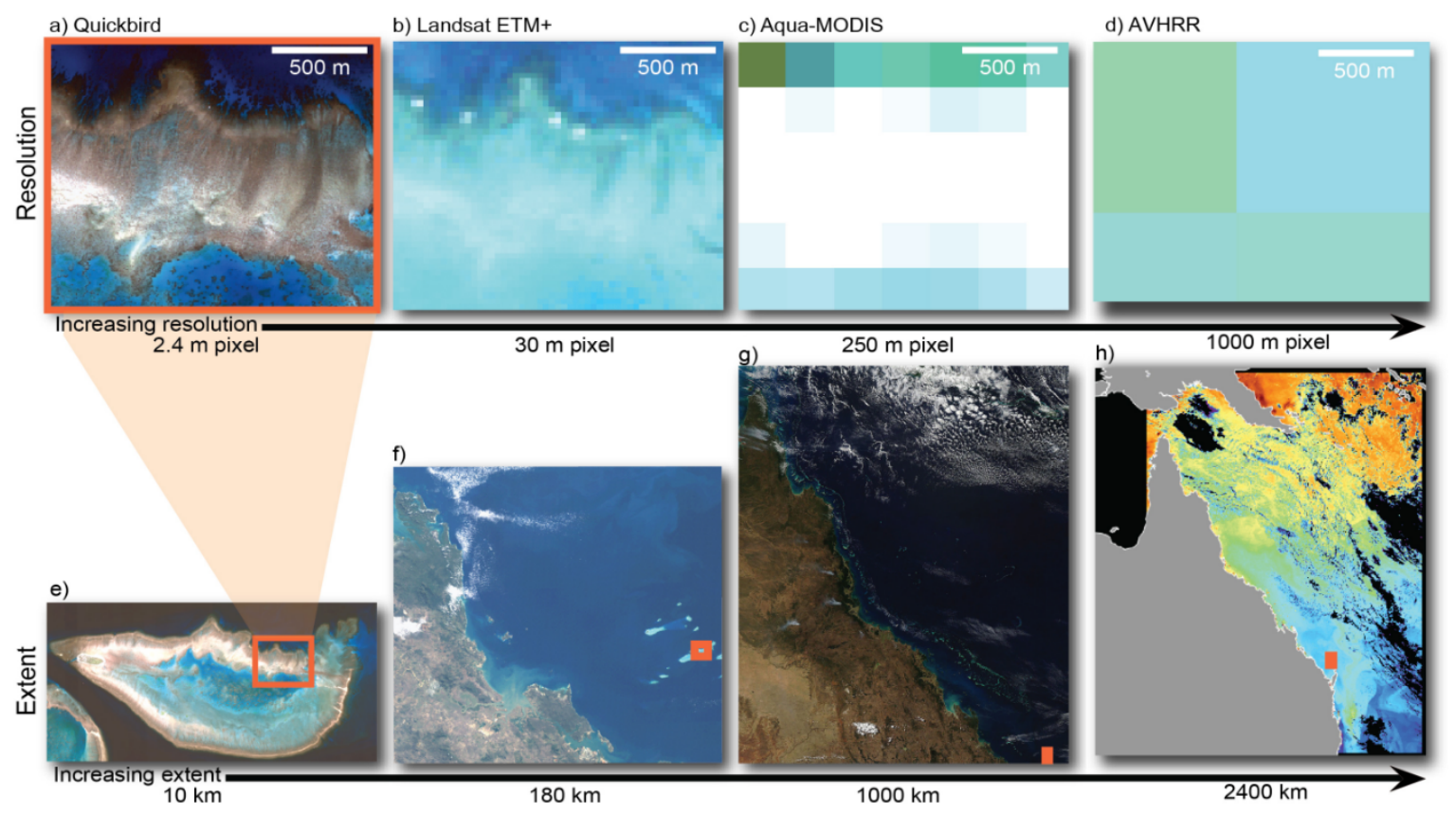

Figure 2. The different spatial dimensions of remote sensing data for an image of Heron Reef, Australia. Images (a-d) show the effects of progressively larger pixel sizes for a $1.5 \mathrm{~km}$ long section of Heron Reef, Southern Great Barrier Reef, Australia; Images (e-g) show different image extents; starting at Heron Reef (e) and moving to the entire Great Barrier Reef (h); Advanced Very High Resolution Radiometers (AVHRR) imagery provides information at oceanographic scale (modified from [36]).

Since reefs cover areas of tens to hundreds of square kilometres, mapping reef extent through remote sensing technologies is most cost effective by moderate resolution satellites (pixel sizes 10 to $30 \mathrm{~m}$ ). The Landsat series of sensors have been used for data acquisition on coral reefs since 1984, and therefore have the advantage of a long time series archive. Landsat has been used to produce a comprehensive inventory of reef structures around the globe [45]. The Sentinel 2 MSI sensor will provide similar data to Landsat 8 , but a spatial resolution of $10 \mathrm{~m}$ in some bands may offer improved capability for coral reef mapping [46] (at the time of writing Sentinel 2 has been launched but images are not yet generally available). In particular, Landsat 8 and Sentinel 2 data is freely available.

Mapping localised reefs can benefit from high resolution satellite data (pixel sizes less than $10 \mathrm{~m}$ ), options for which have proliferated in recent years: Ikonos, GeoEye, Quickbird, WorldView 2 and 3, and Pleiades, having pixels sizes from 1.8 to $4 \mathrm{~m}$. These commercially operated data sources can be expensive for large areas but have become increasingly popular choice for habitat level mapping [32,47-50]. This is in part due to the improved visibility of these products through platforms such as Google Earth ${ }^{\circledR}$ or the data providers' online search systems. Airborne data acquisition from aeroplanes (and increasingly unmanned aerial systems [51]) offers the highest possible spatial resolution, potentially sub-meter pixels, and typically hyperspectral cameras are deployed, giving a high level of information for classification. However the resulting datasets are voluminous even when covering comparatively small areas. Processing is not straightforward, requiring stitching of multiple acquisitions collected with variable geometry and illumination conditions. Nevertheless some large scale mapping exercises for areas of $600 \mathrm{~km}^{2}$ or more have been achieved with high resolution data [52,53].

At the highest end of the spectrum of "descriptive resolution" [38], are individual biotypes, such as remote sensing of live coral cover, coral bleaching and coral mortality. These kinds of objectives have only been demonstrated in limited cases covering relatively small extents of reef and cannot be considered generally possible $[29,43,44,54]$. Mumby et al. [29] showed that hyperspectral imagery was capable of detecting dead versus live corals after a mass bleaching event in $3 \mathrm{~m}$ depth where 
coral density was high and spectrally similar brown macrophytes were absent. Hamylton [44] has demonstrated separation of live and dead coral in a Red Sea site with limited coral diversity and reef structure. Similarly, Riegl and Purkis [55] were able to differentiate between live and dead coral using Ikonos imagery in an area of greater than 50\% coral cover but not in deep or heterogeneous reefs. Modelling studies confirm spectral confusion in heterogeneous or deep areas is a limiting factor for coral cover mapping [56], and the transferability of published successes should always be critically assessed.

For all objectives to be addressed with remote sensing imagery the environmental conditions at the moment of image capture are limiting factors, e.g., water clarity, surface roughness, water depth. For some of these factors, pre-processing of the remote sensing imagery can improve the potential for deriving biophysical properties, and the results will depend on the effort invested in these steps. Necessary pre-processing steps may include image radiometric, atmospheric and geometric correction [57]; sun glint correction [58,59], application of depth invariant bands and correction for air water interface [60-62]. All of these pre-processing techniques become challenging to apply consistently at large scales. Further, there is an upper limit to what can be achieved: the mixed composition of reefs at sub-metre scales and spectral and structural diversity of the benthos introduces fundamental uncertainties in the relationship between benthic cover and above water reflectance [56]. The composition of the reef itself is therefore a factor that can limit achievable mapping accuracies [63], for example, mapping live coral would be more achievable on a reef dominated by massive colonies with no macroalgae than on a more compositionally diverse reef [29]. The environmental context of the reef also influences the accuracy of the classification, with deeper, more turbid areas creating higher uncertainties for benthic mapping [56,64]. When using habitat maps for management activities such as marine spatial planning, these limitations can be taken into account by including explicit information on the accuracy of the features into the planning process [65].

\subsection{Field Data for Calibration and Accuracy Assessment}

In all mapping techniques there is a need for associated calibration and validation methods [65-69]. A variety of approaches can be used for the collection of field survey data that can then be used for the calibration of the mapping process or accuracy assessment of the maps produced. These data collection methods include: local knowledge [70]; expert knowledge [45]; spot checks [71-73]; manta tows [40]; transects [74]; quadrat surveys [49,75]; aerial photography [76]; and photo or video transects [62,77], see also the review in [65]. Which field survey approach to use is a trade-off between the validity, statistical power, available resources and overall cost of the field data collection. The sampling design needs to be developed with these considerations in mind and should include: sample method, sample unit, number of samples, spatial distribution of samples with respect to the data they are likely to contain. See references $[67,68]$ for a discussion of accuracy assessment in general terms, and reference [65] for interpretation in a coral reef context. Useful in situ data not only includes direct information on the composition and abundance of benthic and substrate cover type, but also auxiliary data such as spectral reflectance characteristics of endmembers making up the bottom surface above-water reflectances. Such data can be useful for intermediate validation or quality checking; for atmospheric corrections for example. Data on environmental conditions is also useful, such as temperature, currents and optical water column properties such as backscatter and attenuation. When considering the application of a specific analysis to coral reef imagery, the availability of the required in situ data should be considered. In particular, final accuracy assessment may be limited by the lack of suitable in situ data. The maps may be accurate, but lack of validation data or data with inappropriate structure (e.g., bottom type classification) may mean that the accuracy cannot be proven.

\subsection{Categorical Habitat Mapping}

This section discusses the objective of spatially mapping habitat classes by methods where the relationship between the remotely sensed data and the habitat class is largely characterised by 
in situ training or calibration data. The term habitat is in general not clearly defined; habitat definitions are subjective and, depending on which activity leads the definition, may relate to interpretation by ecologists or what can be distinguished in a remote sensing data set. A habitat may be defined by geomorphology, geology, biotic composition or even geological history [78]. Nevertheless habitats are the most practical level of description for coral reef mapping, since the scale of habitats are usually greater than that of image pixels, whereas the basic components of a habitat (e.g., corals, algae, rubble) frequently are at sub-pixel scales.

Several empirical habitat mapping approaches have been used to create coral reef habitat maps of reefs at different descriptive resolutions. Aerial photography is still of use for producing maps of benthic community by manually delineating polygons [79]. Given that cameras are now digital there is a convergence between remote sensing imagery and photography, algorithms such as classification can be applied to photographs [80]. Similarly, manual delineation can be an efficient way of delimiting geomorphic zones in medium spatial resolution multi-spectral satellite imagery, as was done in the Millennium Coral Reef Habitat Mapping Project [45]. Pixel based classification of multi or hyper-spectral imagery is straightforward to conduct using standard software functions when the area of interest is within a single image $[49,77,81]$. Mosaicking of multiple images is more challenging since radiometric normalisation or some kind of post-classification alignment is required. The classification method can be supervised: where the classification is guided by being told what certain locations are; or, unsupervised: where the algorithm automatically delimits classes and the operator ascribes meaning to each class afterwards [38]. Instead of using generic classification algorithms, another approach is to develop specific criteria for classification based on band ratios or derivatives. The wavelength bands and criteria that might be useful for discriminating reef bottom types has been much discussed in literature [82,83], while some practical demonstrations with remotely sensed imagery have been made [29], it is not the case that any specific spectral features have become widely adopted across multiple studies. Custom classification criteria therefore remain rather ad-hoc and restricted to single studies.

A relatively new approach to create habitat maps is to apply Geospatial Object Based Image Analysis (GEOBIA, or simply OBIA, Figure 3) to high spatial resolution imagery. Object based analysis does not only consider the spectral reflectance (colour) of each pixel, but also the texture, location, shape of groups of pixels, and also optionally the relationship to externally derived environmental factors, such as depth or exposure [84,85]. Object based analysis contains two steps: (1) segmentation and (2) classification of the segments. The segmentation process determines the size, shape and number of segments to which image pixels are grouped, which depends on the required spatial mapping detail. Segments are then assigned a class through membership rules based on colour, texture, shape, size, position and relation to the environmental properties map of the area. While a commonly used approach in terrestrial environments, publications of the application of GEOBIA in coral reef environments are increasing in recent years. Early applications were for seagrass cover [86] and coral reef cover type [40], Promising results have been shown in applying OBIA in various coral reef environments to create habitat mapping at various spatial scales e.g., reef scale, geomorphic zones, and benthic community scales [87] and recent work on seagrass mapping has developed semi-automated OBIA for time series analysis [88]. An example of OBIA based benthic mapping using hyperspectral data is given by Zhang et al. [89]. Compared to per-pixel classification, the key advantages of object based analysis are the potential to combine biophysical and location information with remote sensing imagery, the ability to use spatial patterns as information, and the efficient creation of thematic maps at various hierarchal levels.

Finally, a recent paper by Zhang [90] applies "data fusion" to combine hyperspectral data, aerial photography and bathymetry data, which are then applied in an ensemble analysis of three classification algorithms for coral reef benthic mapping. With the ever-increasing availability of remote sensing data from different sources, future developments may well see increased use of data fusion techniques. 


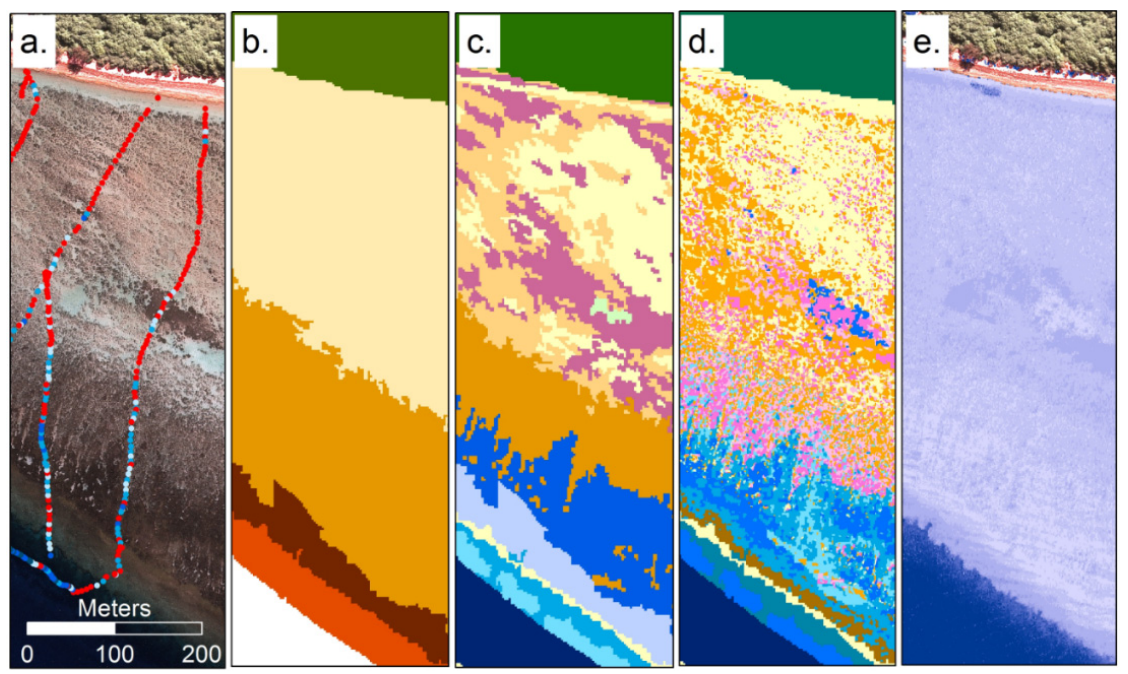

Figure 3. Examples of remote sensing products for an area of reef south of Heron Island (Southern Great Barrier Reef): (a) derived from high spatial resolution imagery and field data; (b) where geomorphic zonation; (c) benthic community; (d) benthic cover type were derived using object based image analysis [87] and (e) water depth derived from model inversion analysis of hyperspectral CASI imagery [91].

\subsection{Quantitative Benthic Mapping}

The previous section described categorical mapping approaches, however some studies have demonstrated quantitative mapping of a continuous benthic parameter such as live coral cover [92], seagrass standing crop [93] or seagrass biomass [94,95]. In these examples the analysis was based on the correlation between image bands (or combinations of bands) and field data on the parameter of interest. This kind of approach is potentially straightforward if in situ data can be obtained and accurately located in the image. However, the interaction between the spatial resolution of data, spatial scale of in situ surveys and accuracy of geo-location continues to present challenges. This can be a problem for establishing the regression model and for accuracy assessment [94]. Quantitative maps can also be produced by methods based on radiative transfer models, in principle these do not require collection of in situ calibration data. These methods are discussed in the Bathymetry and Rugosity section (Section 2.6), below.

\subsection{Coral Bleaching and Change Detection}

Detecting changes in habitat or coral bleaching (the stress-induced expulsion of the symbiotic microalgae from the coral host) are similar objectives in that they require spatially aligning two or more images and identifying regions of change, which must at the very least be apparent as a change of colour or brightness in the co-located image pixels.

When discussing "coral bleaching" it is important to disambiguate the process of bleaching from the perceived effect of loss of pigmentation. The whitening effect of bleaching is not in proportion to relative symbiont loss [96], and various colourations [8] and spatial mixing [97], mean that optical techniques may underestimate the incidence observed in the field, and certainly underestimate the activity of the process $[98,99]$. A single time point exercise in mapping bleaching would be limited by spectral confusion between bleached coral and sand, image differencing after radiometric normalisation offers the most promise for bleaching detection [54,100]. Image comparison requires good spatial registration of imagery, and since this registration cannot be assessed at sub-pixel scales only events greater than one pixel in size can be reliably assessed. To detect the colour changes due to bleaching, images are normalised (essentially values are re-scaled) to remove differences due to the atmosphere, solar and view angles, etc. Various methods utilising Pseudo-Invariant Features (PIFs) have been 
proposed [54,100,101], and the choice of these features may be important for accuracy [101]. Sediment resuspension events may also confound reliable bleaching detection by cross-image comparison. Bleaching detection also requires temporal availability of data that can be compromised by cloud and sea state. In conclusion, while under certain circumstances bleaching detection by satellite data is a realistic objective, many practical considerations mean that routine monitoring for bleaching events is challenging.

Change detection or time series analysis has many of the same practical considerations as bleaching detection. Due to long-term free data availability Landsat has been used in the majority of change detection analyses, and coral habitat decline over long time scales has been detectable (e.g., 18 years [102]). Changes in the extent of seagrass areas are relatively easily detected since the beds are typically clearly delimited and can occur on large scales [88,103,104] (Figure 4). Detecting changes in coral and algae is more challenging due to their spectral similarity and the complexity of the reef composition [103]. To ensure image classifications from different time points are comparable, careful pre-processing is required: use of Pseudo-Invariant Features is common to radiometrically align images [102,105]. Spatial mis-registration between individual time series images and also between imagery and field data, or variation between mapping methods, also limit the consistency of time series habitat maps [106]. However visual interpretation is a powerful and reliable tool for change detection, the majority of sensors providing regular revisit times are multispectral (Landsat, Sentinel 2), so RGB composites capture most of the information present. Knudby et al. [103] showed that classification offered little advantage over visual interpretation of changes, and required substantially more processing effort for little benefit.

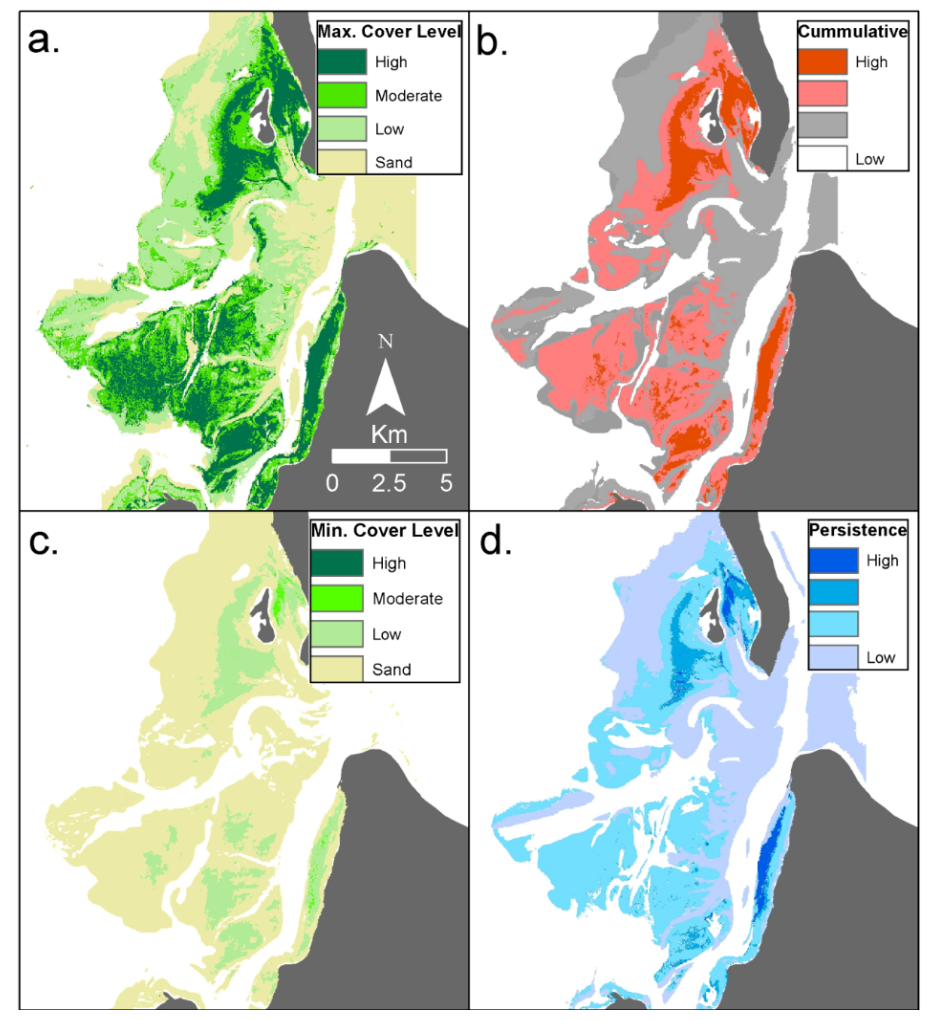

Figure 4. Example of time series analysis for thematic seagrass cover maps for Eastern Banks, Moreton Bay, East coast Australia, derived from twenty two Landsat satellite images on annual basis from 1988-2010. The time series analysis products include maps representing: (a) Extent of maximum and (b) minimum seagrass cover level; (c) Cumulative seagrass cover level and (d) seagrass cover level persistence over time (measure of the amount of variation from the most frequently occurring pixel, analogous to standard deviation) [104]. 


\subsection{Bathymetry and Rugosity}

Maps of reef bathymetry are a useful resource not only for characterising the site and field survey planning, but also for bio-physical modelling, such as currents, thermal transfer and wave energy exposure estimates [107]. Maps of bathymetry can be derived from boat-based sonar or echo-sounders, airborne LIDAR systems, or estimated from optical multispectral or hyperspectral imagery.

Boat-based sonar based systems can offer the advantage of providing not only bathymetry but bottom type characteristics. Acoustic Ground Discrimination Systems (AGDS) allow classification of sea floor features such as sediment hardness, sediment grain size, compaction of sediment, and roughness of terrain, based on the shape and strength of echoes generated [108,109]. Topographic complexity of reef areas has been determined by acoustic echo sounder surveys [109-111]. Distinguishing microhabitats based on their physical features using AGDS, and establishing the effectiveness of measured features to act as surrogate measures of diversity and abundance of juvenile reef fish, can provide information critical for marine resource management [112-114]. In coral reefs, the most important aspects of structural complexity are rugosity, hard substrate, and refuge availability [115], the first two factors can be derived using acoustic techniques. Several studies have shown that combining acoustic and optical remotely sensed data can improve the accuracy of classifications of reef habitats [55,116-118]. One of the main disadvantages of sonar is the difficulty of surveying or traversing very shallow waters that the boat cannot safely access: typically less than 3 to $5 \mathrm{~m}$, although the exact limiting depth depends on the type of sensor and survey vessel. Characterising the reef crest or shallow reef flats by these methods may not be possible, or at best will be hampered by tide and sea state.

Like acoustic techniques, airborne LIDAR systems have been used to quantify the topographic complexity in coral reef ecosystems [119,120]. In a comparison of in situ and LIDAR derived rugosity [121] in situ measured rugosity was a good explanatory parameter of fish assemblage structure while the LIDAR based rugosity showed the same pattern but a weaker relationship. This underlines the key trade-off for remote sensing techniques: assessment of larger scales but with less precision at a point than with in situ surveys. Costa et al. [122] compared the ability of airborne laser and boat-based acoustic technologies to describe shallow reef seafloor topography: both tools were equally capable of discriminating different categories in the seabed topography, but the airborne laser technologies were more time and cost-effective. The characteristics of the study location need to be considered when choosing between the two methods: acoustic sensors collect more spatially detailed data, but they cannot be used in shallow areas. On the other hand, the penetration of laser sensors is inhibited in deep and turbid waters [109,121].

Bathymetry can be estimated from multispectral or hyperspectral imagery, the highest accuracy is obtainable under the clearest water conditions and with minimal surface sun-glint. Maximum reliable depth estimates can be $20 \mathrm{~m}$, but $10 \mathrm{~m}$ is a more realistic aim. In turbid coastal areas, maximum reliable depth may be a metre or less: where the bottom cannot be seen the depth is unknown. Until recently the most common techniques for satellite derived bathymetry were regression approaches, where a logarithmic transform of band pairs is regressed against known depths over consistent bottom types [123-125]. These methods suffer from several drawbacks: (1) requirement of in situ depth data; (2) assumption of constant water conditions across the site; (3) sensitivity to bottom reflectance; (4) only using two bands does not exploit all the information in multi- or hyperspectral imagery. In general the accuracy of these methods is considered low compared to the use of active remote sensing approaches such as sonar or LIDAR, however they are very cost effective over large areas and adequate for some applications.

A comparatively new approach for analysis of optical remote sensing data from shallow-water regions is that of physics-based inversion methods [126]. In these approaches a radiative transfer model is developed that simulates the spectral remote sensing reflectance dependent on water depth, optical properties (e.g., dissolved organic matter and phytoplankton concentrations) and bottom type. An inversion procedure is applied to deduce which set of input parameters produces the closest match 
to the image reflectance in each pixel; using successive approximation or look-up tables [43,91,127-129]. By this method all model input parameters are estimated at every pixel. These methods are therefore not reliant on an in situ calibration dataset, while such information is always useful it is possible to apply physics based methods with no site-specific in situ data at all. The majority of published studies are based on the model developed by Lee et al. [130,131] which in turn was developed by reference to the radiative transfer model HydroLight [132]; which has also been used directly in model inversion applications $[127,133]$. Therefore currently all physics-based inversion methods are at their core very similar and reported differences in performance [126] are due to details in the application. One disadvantage of physics-based methods is that imagery must be radiometrically accurate, i.e., in units of reflectance, and atmospherically corrected. Atmospheric corrections over shallow waters are non-trivial and off the shelf solutions give mixed performance [134]. While these methods estimate bathymetry, bottom type, and water column optical properties simultaneously not all parameters are equally reliable. One advantage of these methods is that they are amenable to numerical uncertainty propagation, providing error bars on all estimated parameters at every pixel [46,135]. Bathymetry estimates are quite robust largely because the absorption by pure water in itself has a very strong gradient from the blue to red wavelengths [91,127]. Bathymetry can be estimated with good accuracy using model inversion on multispectral data and, given suitable model parameterisation, is not as sensitive to bottom type as with regression methods. The utility of mapping bottom type with physics-based methods has yet to be fully developed, while some studies have focused on this application $[43,128,133,136]$ habitat classification methodologies (Section 2.3) remain the primary applied methods for bottom type mapping.

\subsection{Related Terrestrial Environments, Coastal Development and Human Activities}

The number of people in a given area is one of the most quoted causes of decline of ecosystem health, with higher human densities leading to higher levels of influence on nature [137]. Coastal development, the transformation of natural coastal areas to build human settlements, produces a physical change to the landscape through the destruction of coastal ecosystems and the modification of the shoreline [138]. These alterations can affect natural ocean circulation patterns, runoff, erosion and sedimentation processes, reduce the availability of nursery areas for coral reef inhabitants and adversely affect the function of coral reef ecosystems $[139,140]$.

Coastal development is frequently associated with changes in land use and the clearing of natural coastal ecosystems [139]. Land cover mapping is one of the earliest applications of remote sensing technology, and can be achieved using optical instruments across the range of available spatial resolutions, from detailed airborne imagery to low resolution data, according to the required area of observation and the purposes of the study (see reviews by Cihlar [141] and Franklin and Wulder [142]). The quantification of changes in cover classes for the description of anthropogenic trends is also a well-researched topic (see reviews by Gillanders et al. [143] and Lu et al. [144]). These techniques have been used in coastal areas to assess urban development [145], coastline changes [146] and mangrove clearance [147], enabling the quantification of the human impact on coastal ecosystems. Mangroves in particular are important associated environments to coral reefs, providing nursery grounds for reef fish [140], and are the subject of ongoing research in remote sensing methodologies [148]. Habitat maps also provide the basis for calculating indexes of inter-habitat connectivity [149] that are useful for a range of ecological and conservation questions.

Overfishing is one of the main causes of reef degradation at a local scale. Destructive fishing practices cause substantial structural damage to coral reef habitats [139]. Fishing results in a decrease in fish abundance, fish size and ultimately in changes in species composition within reef communities [138]. Overfishing of herbivorous fishes can promote the degradation of reef communities by promoting the growth of algae, which can out-compete corals and inhibit the settlement of coral recruits $[150,151]$. Although overfishing cannot be directly assessed via remote sensing, it may be possible to relate fishing pressure to quantifiable characteristics of fishing settlements, including 
the distance to the reef, access to neighbouring markets and available electrical power. Increased proximity to fishing grounds improves the cost-effectiveness of the fishing procedure, while improved accessibility to fish markets (via more and better roads) increases the ability to sell the catch [152,153]. Additionally, electrical power facilitates the storage of fish [7]. Wave exposure, measurable from remotely sensed wind and configuration of the coastline [154] also determines site accessibility and fishing pressure, particularly for small vessels [155]. All these elements can be assessed using remotely sensed imagery and GIS techniques. Reefs, fishing settlements and roads can be mapped using high and moderate resolution remote sensing [45,141]. Electricity use can be measured as the area illuminated by lights as quantified from satellite images taken at night, and this has been used as a proxy for population distribution and the level of economic development $[7,137,156]$ and to measure anthropogenic indirect impacts on reefs [157]. However, these proxies need to be considered carefully as recent studies have shown that other variables such as the socioeconomic level of the settlement can be more important in determining the levels of extracted fish biomass in locations subjected to fishing [158].

Finally, remote sensing may be used to monitor seascape features that may correlate with fishing pressure. For example, the fear of predators leads to grazing "halos" where herbivorous fish stay close to patch reefs, overexploitation of predators could lead to fishes grazing further from reefs and creating wider or less distinct halos [159].

\section{Environmental Products}

The state of a coral reef is highly dependent on its physical environment: temperature, light, water chemistry and water movement have direct effects on coral survival, whereas those and other factors such as waves interact and act indirectly on reef biota. Remote sensing can both establish the climatology of the physical environment, defining tolerance ranges, and also identify anomalous conditions outside those tolerances which may correspond to environmental stress. One important distinction from the previous section in habitat mapping is that the spatial resolution of sensors typically used for oceanographic environmental parameters are one or two orders of magnitude lower than those available for benthic mapping, so the term "high resolution" in the context of sea surface temperature may mean pixels of size $4 \mathrm{~km}$. This section discusses some of the key physical environmental factors that are assessable by remote sensing and their application to reef monitoring and management, including sea surface temperature, light, wave exposure, ocean colour and carbonate chemistry (Table 2).

\subsection{Sea Surface Temperature (SST)}

The causative link between increased temperatures and mass coral bleaching was established in the 1990s [160]. Corals and their symbionts experience seasonal temperature ranges that define their tolerance thresholds and thus their response to temperature extremes [161-163]. Thermal stress occurs when corals are exposed to prolonged above-normal temperatures, where the level of stress depends on the absolute temperature, the rate of change, and length of exposure [8]. The frequency of mass coral bleaching events due to elevated temperatures has increased since the late 1970s, with the worst events to date being: the 1982-1983 event in the eastern tropical Pacific, Caribbean, and potentially other places around the world [164,165]; the 1997/98 global bleaching event [98,166]; the 2005 event in the Caribbean [33,167]; and the global bleaching event in 2010 [168-171]. Another global bleaching event has been reported during the writing of this paper (including Hawaii, October 2015, Figure 5). The frequency and intensity of coral bleaching is likely to increase in the next few decades [161,172], so that coral bleaching is expected to become increasingly common on reefs, with half of the world's reefs projected to experience annual bleaching by 2040 under a "business as usual" emissions scenario [173]. 
Table 2. Capability for evaluation of environmental factors by remote sensing.

\begin{tabular}{|c|c|c|c|}
\hline Objective/Proxy & Association & Sensor or Technology & Considerations \\
\hline \multicolumn{4}{|l|}{ Photic depth } \\
\hline $\begin{array}{l}\text { Estimation of water } \\
\text { attenuation }\left(K_{\mathrm{d}}\right)\end{array}$ & high & $\begin{array}{l}\text { Ocean colour and multispectral } \\
\text { moderate and high resolution satellites }\end{array}$ & $\begin{array}{l}\text { Newer methods improve on the } \\
\text { limitations of standard ocean } \\
\text { colour algorithms in shallow } \\
\text { coastal waters }\end{array}$ \\
\hline \multicolumn{4}{|l|}{ Sedimentation } \\
\hline Turbidity & medium & $\begin{array}{l}\text { Ocean colour and multispectral } \\
\text { moderate and high resolution satellites }\end{array}$ & $\begin{array}{l}\text { Seafloor reflectance in shallow } \\
\text { waters limits the quantification of } \\
\text { in-water constituents }\end{array}$ \\
\hline \multicolumn{4}{|l|}{ Pollution } \\
\hline Turbidity & low & $\begin{array}{l}\text { Ocean colour and multispectral } \\
\text { moderate and high resolution satellites }\end{array}$ & $\begin{array}{l}\text { Direct quantification of pollutants } \\
\text { is not feasible using remote } \\
\text { sensing. Turbidity monitoring } \\
\text { offers a proxy for the assessment } \\
\text { of pollutant pathways }\end{array}$ \\
\hline Algal blooms & low & Ocean colour satellites & $\begin{array}{l}\text { Algal blooms, often triggered by } \\
\text { pollution enrichment, can help } \\
\text { pinpoint polluted areas }\end{array}$ \\
\hline \multicolumn{4}{|l|}{ Exposure } \\
\hline $\begin{array}{l}\text { Wind energy and } \\
\text { bathymetry }\end{array}$ & medium & $\begin{array}{l}\text { Satellite scatterometers for wind } \\
\text { (see Table } 1 \text { for bathymetry) }\end{array}$ & $\begin{array}{l}\text { Calculation of wave energy can be } \\
\text { done by simple calculations or a } \\
\text { full numerical model }\end{array}$ \\
\hline \multicolumn{4}{|l|}{ Coastal development } \\
\hline Changes in land use & high & $\begin{array}{l}\text { Multispectral high and moderate } \\
\text { resolution satellites, airborne sensors }\end{array}$ & $\begin{array}{l}\text { Changes in land use resulting in } \\
\text { the loss of habitats and the } \\
\text { modification of coastlines is a } \\
\text { good proxy for the quantification } \\
\text { of coastal development }\end{array}$ \\
\hline \multicolumn{4}{|l|}{ Overfishing } \\
\hline $\begin{array}{l}\text { Distance to reef-fishing } \\
\text { settlements, } \\
\text { accessibility }\end{array}$ & low & $\begin{array}{l}\text { Airborne remote sensors, multispectral } \\
\text { high resolution satellites }\end{array}$ & $\begin{array}{l}\text { Settlements located near to reefs } \\
\text { are more likely to exploit their } \\
\text { resources, while accessibility } \\
\text { (number and quality of roads) } \\
\text { improve the distribution of the } \\
\text { catch and stimulate its increase }\end{array}$ \\
\hline $\begin{array}{l}\text { Electrical power } \\
\text { (night time } \\
\text { illumination) }\end{array}$ & low & Spatially low resolution radiometers & $\begin{array}{l}\text { Areas with higher electrical power } \\
\text { are more likely to have the } \\
\text { appropriate storage systems that } \\
\text { support larger fisheries }\end{array}$ \\
\hline \multicolumn{4}{|l|}{ Thermal stress } \\
\hline Sea surface temperature & high & Spatially low resolution radiometers & $\begin{array}{l}\text { The only stress variable that can } \\
\text { be directly measured using remote } \\
\text { sensing. Proven to be useful in the } \\
\text { forecasting of bleaching events } \\
\text { and hindcasting of bleaching } \\
\text { severity }\end{array}$ \\
\hline \multicolumn{4}{|l|}{ Ocean acidification } \\
\hline Sea surface temperature & low & Spatially low resolution radiometers & $\begin{array}{l}\text { Together with in situ datasets can } \\
\text { be used to model the effects of } \\
\text { increased } \mathrm{CO}_{2} \text { concentrations in } \\
\text { water chemistry }\end{array}$ \\
\hline
\end{tabular}

Of all the stressors affecting coral reef ecosystems, temperature is the one that can be measured the most directly by remote sensing, in the form of sea surface temperature (SST). Instruments on polar- and geostationary-orbit satellites, such as the U.S. National Oceanic and Atmospheric Administration's (NOAA) Advanced Very High Resolution Radiometers (AVHRR), can provide near real-time observations of SST around the globe. A number of different coral reef thermal 
stress indices from sea surface temperature (SST) data have been developed, these indices relate bleaching incidence and severity to: (1) absolute values of sea surface temperature; (2) overall averages related to thresholds derived from the summer maximum or warmest monthly average temperature; (3) magnitude of temperature anomalies; (4) the duration of temperature anomalies; (5) the sum of temperature anomalies over time; or (6) rates of change of temperature. Although all the different metrics have proven to be useful for the prediction of bleaching in certain locations and times, a full cross-comparison of their efficacy is lacking [162,174]. Note that satellite instruments measure SST from the top few millimeters of the water column at most (dependent on the sensor used) so the implicit assumption of all these studies is that the surface temperature metrics provide useful environmental information with respect to corals that typically live metres to tens of metres below the surface.

The only global and most mature set of SST products for coral reef management are those of NOAA's Coral Reef Watch program (CRW), which have been developed since the 1990s and are freely available online (http:/ / coralreefwatch.noaa.gov) (Figure 5). The "heritage" Decision Support System (DSS) consists of near real-time products [175] that were developed based on earlier analyses of satellite and in situ SST data published in several papers from 1994 to 2000 [176-179]. Heritage products are produced at $0.5^{\circ}$ spatial resolution (approximately $50 \mathrm{~km}$ ) and updated twice each week. Spatial products include night-time SSTs, their anomalies (HotSpots), accumulated anomalies (Degree Heating Weeks), and a bleaching alert area product. These are augmented with data and images for specific reef locations across the world that are provided as time series and linked to an automated email alert system to subscribers when coral reefs in the vicinity are at risk for bleaching.
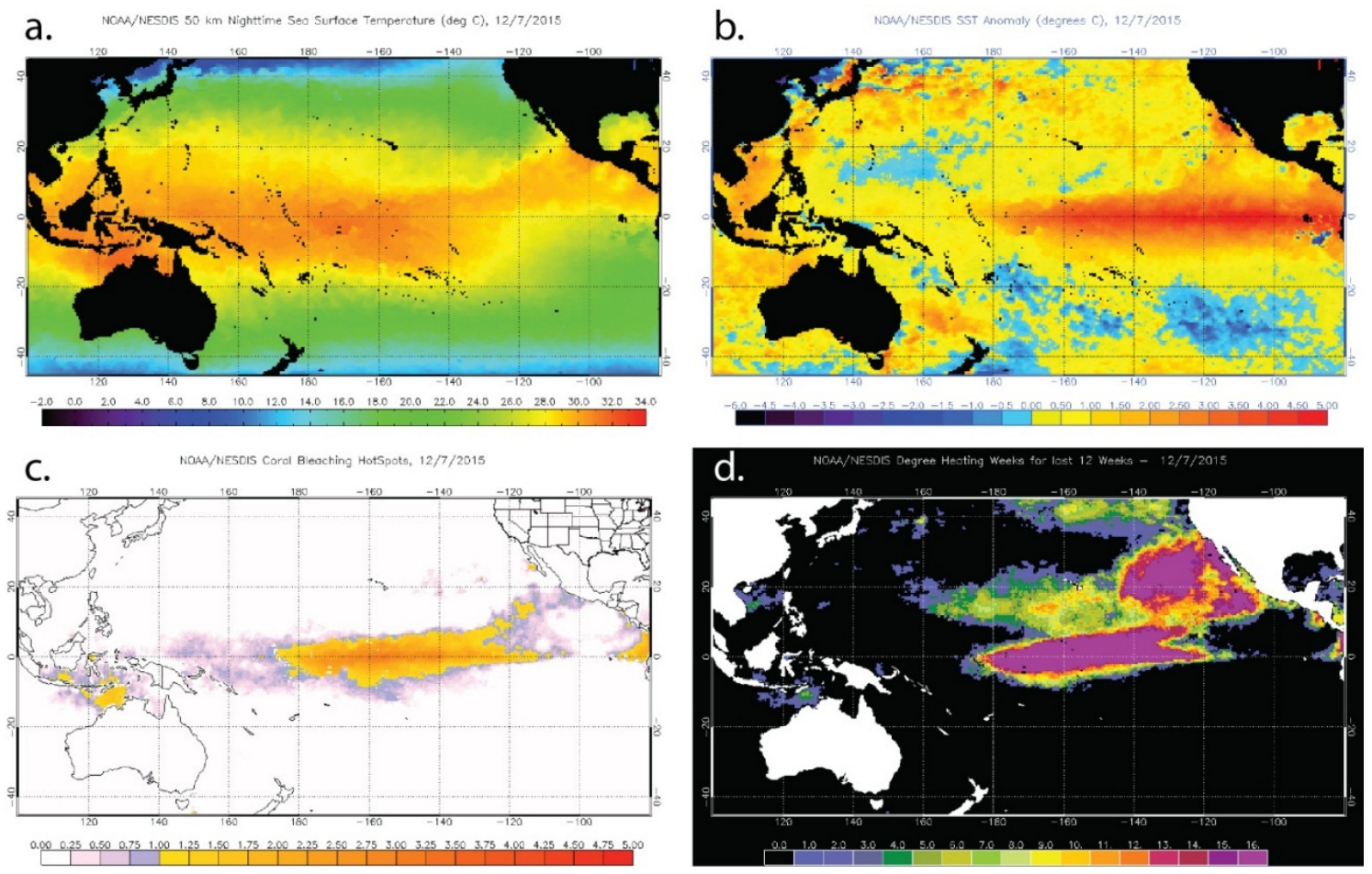

Figure 5. Examples of the U.S. National Oceanic and Atmospheric Administration (NOAA) Coral Reef Watch products for 12 October 2015, a time at which coral bleaching has been reported in Hawaii. (a) Sea Surface Temperature; (b) Sea Surface Temperature Anomaly; (c) HotSpot; and (d) Degree Heating Weeks.

The CRW suite includes two products specifically designed to identify temperature conditions linked to coral bleaching. The Coral Bleaching HotSpots product is the positive anomaly of temperatures exceeding the maximum monthly mean (MMM) from SST climatology for each pixel and identifies regions that are currently undergoing thermal stress [178]. The algorithm is based on the 
"ocean hot spots" concept introduced by Goreau and Hayes [180] using analyses by Atwood et al. [181] and experiments by Glynn and D'Croz [160]. The response of corals to the cumulative thermal stress to which they are exposed is captured by the Degree Heating Weeks (DHW) product that accumulates the HotSpot values equal to or greater than $1^{\circ} \mathrm{C}$ in each pixel over a 12-week period [182,183]; the threshold of $1^{\circ} \mathrm{C}$ above the MMM was established by Glynn and D'Croz [160] and Atwood et al. [181]. Significant coral bleaching is expected to occur 1-3 weeks after reefs begin to experience DHW values of $4{ }^{\circ} \mathrm{C}$-weeks or greater. Mass bleaching and the onset of coral mortality are expected after reefs experience DHW values greater than $8{ }^{\circ} \mathrm{C}$-weeks.

Recently, a $5 \mathrm{~km}$, daily-updated Decision Support System (DSS) was launched [184], with further products subsequently added [184]. The $5 \mathrm{~km}$ SST is derived using full-resolution data from multiple POES and Geostationary Orbiting Environmental Satellites (GOES) instruments: an order of magnitude more input data than the heritage DSS. Qualitative analysis for the $5 \mathrm{~km}$ DSS has indicated strong performance in the Pacific [185] and Caribbean [M. Eakin, private communication] during 2013-2015. The first quantitative analysis for the $5 \mathrm{~km}$ DSS [185] confirmed the use of these products to monitor coral bleaching in the Northern Mariana Islands during 2014. The $5 \mathrm{~km}$ DSS is, at present, being used to guide reef stakeholders to undertake targeted coral surveys; the resulting dataset of observations will be used for further quantitative comparison with these monitoring products.

The logistics of satellite data transmission are such that in some cases full spatial resolution local area coverage (LAC) data was available only at local receiving stations and not in the final global products. An example of an online environmental monitoring program that exploits regional POES SST data is ReefTemp (http:/ /www.cmar.csiro.au/remotesensing/reeftemp/web/ReefTemp.htm) [186], a project developed jointly by the Great Barrier Reef Marine Park Authority (GBRMPA), the Commonwealth Scientific and Industrial Research Organisation Marine Research (CSIRO-MR) and the Australian Bureau of Meteorology (BoM). Building from this, an operationally supported update, ReefTemp Next Generation (http://www.bom.gov.au/environment/activities/reeftemp/ reeftemp.shtml), is now produced in near real-time by the BoM [187]. ReefTemp is a suite of $2 \mathrm{~km}$ resolution SST-based products for the GBR providing a regional map of bleaching-related thermal stress, updated each day using an up to 14 day SST composite. A second regional example is from the University of South Florida's Institute of Marine Remote Sensing, providing thermal stress monitoring for the Florida and eastern Gulf of Mexico region (http://imars.marine.usf.edu/crw-dss) [188]. SST data from POES AVHRR and NASA's Moderate Resolution Imaging Spectroradiometer (MODIS) are used to calculate the CRW HotSpots and DHW metrics twice each week. Note that more-recent satellites have the ability to store LAC data on-board, allowing the parent and collaborative organizations to download full resolution global datasets.

In addition to the operational near-real-time satellite observations, retrospective reprocessed datasets of satellite SST data have been produced and periodically updated, using the benefit of hindsight to reduce any systematic biases. For example, the NOAA Pathfinder dataset (http:/ / www.nodc.noaa.gov/sog/pathfinder4km) [189] has permitted an examination of recent global and regional trends in SST anomalies [190,191] and thermal stress [192,193].

Using global sea surface temperature (SST) forecast models it is possible to extend the near real-time monitoring algorithms into forecasting. The first NOAA CRW Outlook system was released in 2008 [194], based on the statistical Linear Inversion Model system, but has had observed issues in specific reef locations. CRW's primary forecast system is now the Four-Month Coral Bleaching Thermal Stress Outlook (http:/ / coralreefwatch.noaa.gov/satellite/bleachingoutlook_cfs / outlook_cfs.php) [195], which uses the National Centers for Environmental Prediction's (NCEP) Climate Forecast System Version 2 (CFSv2). Version 3.0 of this product is available at $0.5^{\circ} \times 0.5^{\circ}$ and weekly resolution and up to four months into the future, and is based on probabilities derived from an ensemble model approach. The Australian BoM also produces SST anomaly five-month forecasts for the Great Barrier Reef based on the POAMA model (http:/ /www.bom.gov.au/oceanography/ oceantemp/GBR_SST.shtml) [196]. 


\subsection{Solar Radiation}

In addition to the important role of temperature in bleaching, light levels have also been implicated as a causative factor $[197,198]$ and it has been suggested that cloud cover may protect against bleaching even when SSTs are elevated [199]. Products that estimate solar radiation incident at the top-of-atmosphere (TOA), such as provided by the Solar Radiation and Climate Experiment (SORCE) (http://lasp.colorado.edu/sorce/index.htm), are of use for climate modelling; however, they do not factor in light attenuation by the atmosphere or clouds. For research and management of coral reefs the primary remote sensing products of interest are those that provide bottom-of-atmosphere (BOA) estimations of the light incident onto the water surface. Operational satellite-derived surface solar radiation products have traditionally been developed for commercial use such as mapping the viability of solar energy technologies, scheduling power plants via models that forecast power usage and in some cases modelling the contribution of solar power generation. Other uses have been associated with skin cancer research and forecasts of UV indices for public use.

Until recently the development of satellite-based solar radiation products for coral reef applications suffered from low temporal resolution and navigation accuracy issues. Due to cloud movement it is necessary to have a very high temporal resolution for data to fully characterise daily light in terms of both peak and time integrated light levels. While instantaneous measurements from Polar Orbiting Environmental Satellites (POES) such as SeaWIFS and MODIS may be accurate, their orbits of one or two overpasses each day are inadequate for daily estimates of total solar radiation. In general, the aforementioned solar radiation products do not claim to deliver time-integrated totals of surface solar radiation for periods of less than one week. Errors in estimated daily radiation from satellites have been shown to decrease when multiple measurements are used for each day [200].

Geostationary satellites can provide multiple acquisitions during the day but each satellite can view only a limited geographic area. Typically, whole-disk or partial-disk observations are provided every ten minutes to every three hours, depending on the satellite. These data can be combined spatially and temporally to provide daily estimates at near-global coverage of many aspects of solar insolation.

Most operational satellite-based solar insolation products provide data over the ocean and coral reefs. The Australian Bureau of Meteorology (BoM) has archived satellite-derived operational solar radiation products since 1990, transitioning their Global Solar Exposure product (http://www.bom.gov.au/climate/austmaps/metadata-daily-solar-exposure.shtml) through various satellite platforms. Unfortunately, this product is designed to cover the land and although it does provide coverage of near-coast coral reefs, it is not designed for marine use. NOAA has developed a suite of Geostationary Surface and Insolation Products (GSIP) for the GOES East and West satellites, available since early 2009. These products have since been expanded to include MSG and MTSAT starting in March 2014. Development of these products followed a request from NOAA's Coral Reef Watch for total daily global surface insolation over coral reefs. The (current) third version (GSIP-v3) extends the product application to MSG and MTSAT to produce a daily surface insolation product with spatial resolution of $1 / 20^{\circ}(\sim 5 \mathrm{~km})$ that provides near-global coverage (http://www.ospo.noaa.gov/Products/land/gsip/index_v3.html). Hourly and three-hourly data is processed for the GOES East and West full disk are combined with the hourly data from MTSAT and half hourly data from MSG full disk domains.

One example of the use of geostationary satellite data to study aspects of surface solar radiation over coral reefs reported a significant increase in solar radiation on the Great Barrier Reef (GBR) from 1995-2005 [201]. The study found that summer light levels in the (more poleward) southern GBR were higher than in the north, linked to monsoonal cloud activity. Analysis of solar radiation during the 2002 coral bleaching showed that maximum bleaching was co-located with maximum radiation. NOAA's Coral Reef Watch program has developed an experimental Light Stress Damage product for the Caribbean (http:/ / coralreefwatch.noaa.gov/satellite/lsd/index.php) that combines SST with surface estimations of photosynthetically available radiation (PAR) from GSIP-v3. This multi-component metric provides another proxy for bleaching stress that has yet to be fully evaluated. However, 
Barnes et al. [202] recently demonstrated independent associations between satellite estimates of SST, ultraviolet light and wind to coral bleaching incidence in the Florida Keys, indicating that multi-factor estimation of bleaching stress will lead to improvements over SST only algorithms.

\subsection{Wind}

Winds influence the mixing of the upper water layer, not only inflicting mechanical stress in shallow areas but also influencing the vertical composition of the water column-with consequences for the light and temperature environment of corals. Hence wind action may exert an influence on bleaching stress through both factors. When wind speeds drop, reduced mixing may increase the likelihood of high temperatures and light penetration [199,203-205].

Wind speed and direction can be assessed using both passive and active microwave instruments on satellites. The roughness of the ocean surface provides a measure of near-surface wind speed that can be quantified by passive microwave radiometers. On the other hand, radar scatterometers transmit pulses of energy and measure the backscattered energy as a proxy for wind speed. Synthetic Aperture Radar (SAR) also uses backscatter to measure wind speed at higher resolution and closer to land than scatterometers, making them ideally suited for use in coral reef regions [206].

A practical example of remote sensed wind data used in a coral reef monitoring product is the NOAA Coral Reef Watch experimental Doldrums product (http:/ / coralreefwatch.noaa.gov/ satellite/doldrums_v2/index.php), which uses the National Climatic Data Center (NCDC) Blended Sea Winds Product of ocean surface winds. This data set is interpolated from up to six satellite observations (SMI F13, SSM/I F14, TMI, QuikSCAT, SSM/I 15, and AMSR-E), it offers higher temporal resolution than is possible from a single satellite and provides 6 hourly $0.25^{\circ}$ gridded global fields. The current Doldrums product identifies regions where average wind speeds have remained below $3 \mathrm{~ms}^{-1}$ and records the persistence (doldrums-days) of such conditions. These conditions could serve as an additional factor in regions experiencing thermal stress through the reduction of vertical mixing, evaporative cooling and heat transfer. A potential advance for more accurate prediction of bleaching events could be to integrate a doldrums product with SST-based algorithms.

Wave exposure, the degree of wave action on an open shore or reef area, drives the distribution of reef habitats [154], ecological processes such as primary productivity [207], coral growth [208], disturbance incidence [209], fish assemblage structure [210], and defines the spatial pattern of anthropogenic influences such as fishing access [155]. Wave exposure is governed by the distance of open sea over which the wind blows to generate waves, i.e., the fetch, and the strength and incidence of the winds. Archived scatterometer data such as that from QuikSCAT or the European Remote Sensing Satellite (ERS-2) can provide the required time series of wind data that, together with a land mask (see Section 2), can be used to evaluate the wind strength and fetch over a set of incident directions onto a reef location. A basic map of wave energy can be produced by summing the contributions from different incident directions modified by bathymetry. The required calculations are given in Ekebom et al. [211] and, in a coral reef context, Hamylton [212]. For coral reef applications see Harborne et al. [42] and Chollett and Mumby [154]. For a more comprehensive model a numerical wave energy simulation such as SWAN can be employed [213], but the set-up is substantially more onerous.

\subsection{Ocean Colour}

Impacts from land-based pollution and erosion have been long recognized as one of the main threats for coral reefs at local and regional scales [138]. The synoptic view and high temporal coverage provided by remote sensing makes it a desirable tool for the assessment of water quality parameters such as turbidity (e.g., Secchi depth), total suspended solids and chlorophyll concentration on reefs [214-216] (Figure 6). However, reef areas present several challenges for ocean colour instruments. Coral reefs are located in relatively shallow waters, mostly near coastal areas where the colour of the water is determined by a mix of several constituents such as phytoplankton, non-algal particulate matter, and coloured dissolved organic matter (CDOM). In these optically complex waters, the optical 
properties of the water column are influenced by the non-algal constituents that do not necessarily co-vary with respect to phytoplankton abundance [217]. The optical signal received by the satellite is a complex mixture of varying components and this hampers the estimation of in-water constituents.

The signal received by an ocean colour sensor comprises two components: scattered energy from the atmosphere and energy from the water body, over open ocean conditions only $10 \%-20 \%$ of the satellite measured signal originates from the water surface [218]. Hence, the removal of atmospheric effects is crucial to obtaining accurate estimates of water reflectance [219], and this is usually based on the assumption that reflectance in the near-infra-red (NIR) is zero. However, in coastal waters, backscatter from non-phytoplankton particulate material can contribute significant amounts to the NIR reflectance, making the removal of atmospheric effects much more difficult [220]. Additionally, in shallow reef areas light reflected from the bottom produces an optical signal that changes with the depth and nature of the seafloor. In these optically shallow waters, the bottom-reflected light influences the water-leaving radiance signal [130] thereby confounding contemporary ocean colour algorithms developed for optically deep waters [221,222]. This contribution needs to be removed before the water constituents can be quantified, adding another level of complexity to the estimation procedure in these areas [217]. As a result of these complexities, deriving water quality parameters with sufficient accuracy in coastal waters has remained one of the main challenges in marine remote sensing.

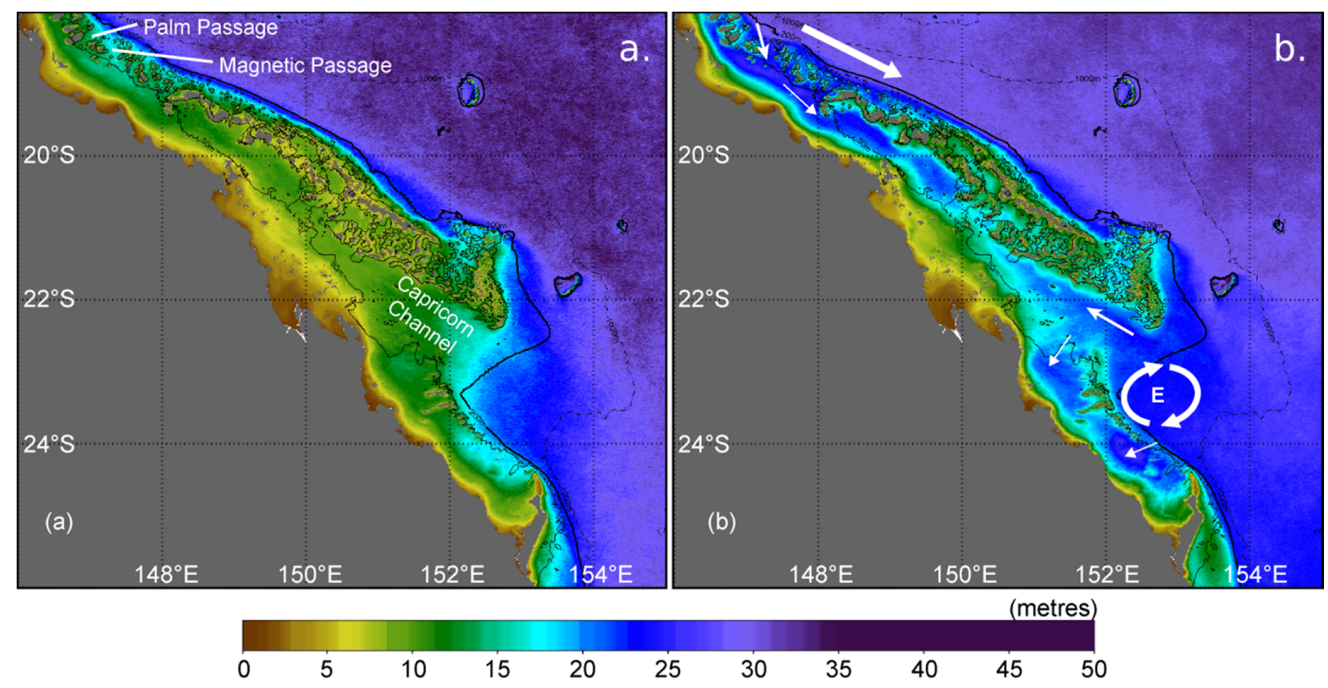

Figure 6. Long-term (2002-2012) monthly mean photic depth (m) on the central-southern Great Barrier Reef showing waters most turbid (a) during March and most transparent (b) during September. The solid black line denotes the $200 \mathrm{~m}$ isobath. The large white arrow represents the southward flow of the East Australian Current, with smaller white arrows showing the directions of oceanic intrusions onto the shelf. The circular arrows show the location of the Capricorn Eddy (E) that forms in the lee of the shelf bathymetry [216].

While recent techniques of radiative transfer model inversions have demonstrated the ability to separate benthic reflectance from water constituents in coral reef environments [127] (see Section 2.6) these demonstrations have largely focussed on bathymetric retrieval and benthic classification from high spatial and spectral resolution data, in many cases from airborne sensors. In coral reef applications there has been relatively little emphasis on derived inherent optical properties (IOP) and water quality measures such as chlorophyll, suspended particulate matter, and water clarity. Current work to extend ocean colour applications to coral reef and coastal regions is actively addressing the two primary challenges of: (i) optically complex and (ii) optically shallow waters [223]. While a range of ocean colour algorithms have now been developed and proven effective in optically complex waters [224-226], only a few approaches for optically shallow waters have been published [227,228], with none of these operational. Most recently, McKinna et al. [223] have developed a quasi-analytical 
ocean colour inversion algorithm, the Shallow Water Inversion Model (SWIM), which explicitly uses water column depth and benthic albedo datasets to improve IOP retrievals in optically shallow waters. SWIM has been incorporated into the NASA SeaDAS processing code and is freely available to the international scientific community (http:// seadas.gsfc.nasa.gov).

Currently, remotely sensed ocean colour data do allow investigation into mesoscale patterns within a reef province. Low resolution ocean colour data have been used to describe disturbance events such as algal blooms [31,229], or to assess qualitatively the turbidity patterns in a reef area, thereby complementing in situ characterisations of water quality [215]. Ocean colour data has also been used to discriminate the relative causes (resuspension or runoff) of high sedimentation rates in a reef area [230] and to assess regular connectivity patterns within a reef region [231-235] or unexpected connectivity patterns following a disturbance event [236]. Detailed sedimentation patterns have also been assessed using moderate resolution satellite images [230].

Detecting changes to the transparency of the water column is critical for understanding the responses of benthic organisms to light availability, especially in shallow coral reef ecosystems $[237,238]$. Coral reefs and seagrass meadows are built by photosynthetic organisms, and are therefore highly sensitive to changes in the water column that affect the attenuation of light. Hence, water transparency is considered a key measure of water quality in coral reef systems. Recent progress in remote sensing applications includes the development of quasi-analytical algorithms for determining the photic depth $\left(Z_{\%}\right)$ from observed satellite radiances [239]. $Z_{\%}$ is a measure of water attenuation with, for example, $Z_{1 \%}$ reflecting the depth where only $1 \%$ of the surface irradiance (PAR, photosynthetic available radiation) remains. The most widely used measure of water transparency in the field is Secchi depth $\left(Z_{\mathrm{SD}}\right)$ : the depth at which a white disc ceases to be visible by an observer above the surface. Whilst not a direct measurement of transparency and somewhat imprecise (Secchi depth can vary as much as $20 \%$ due to solar angle) Secchi depth benefits from a long historical record and millions of measurements worldwide, and recent work has improved the theoretical basis and alignment of Secchi depth with remote sensing data [240]. In one practical application, Weeks et al. [216] used 15 years of regional $\mathrm{Z}_{\mathrm{SD}}$ data to refine and validate the Lee et al. [239] quasi-analytical algorithm for the waters of the Great Barrier Reef, Australia. Implementing the newly-developed photic depth product over a decadal satellite time series, water transparency was shown to vary significantly in time and space, primarily influenced by river discharge and oceanic intrusions. Subsequent studies have also investigated current algorithms to derive the multispectral diffuse attenuation coefficient $\left(K_{\mathrm{d}}\right)$ from satellite data to examine the spatial and temporal variability of water clarity in coral reef ecosystems $[227,241,242]$. The current consensus is that satellite data from moderate resolution sensors such MODIS, and more recently VIIRS (Visible Infrared Imaging Radiometer Suite, on NOAA's next generation Joint Polar Satellite System [243-245]), provide much improved estimates of water clarity conditions in coral reefs, due to the robust, frequent and synoptic coverage. Their use can be recommended as a component of routine monitoring of water quality in shelf and coral reef waters. Nevertheless the primary issue remains that the individual pixels of these sensors are at scales of 100s of metres to kilometres; limiting what can be achieved in spatially heterogeneous areas.

New sensors with improved capabilities (more and narrower spectral bands) will aid atmospheric correction and bio-optical applications. Additionally, application of current algorithms (e.g., SWIM) to recent sensors with higher spectral resolutions such as the Hyperspectral Imager for the Coastal Ocean (HICO, now no longer operational), or those being prepared or planned for launch such as the Ocean and Land Color Instrument (OLCI) aboard ESA's Sentinel-3 mission, and the Ocean Color Imager (OCI) aboard NASA's Pre-Aerosol, Clouds and ocean Ecosystem mission (PACE) [246] will further advance the use of ocean colour data as a valuable resource for coral reef science and management. Acker [247] provides an excellent and comprehensive history of NASA's ocean colour missions from 1971 to 2014 - primarily CZCS and SeaWiFS — which is recommended for those interested in this colourful $4 \frac{1}{2}$ decade oceanographic evolution. 


\subsection{Carbonate Chemistry and Ocean Acidification}

Dissolved carbon dioxide $\left(\mathrm{CO}_{2}\right)$ in the ocean surface layer will likely double over its pre-industrial value by the middle of this century, representing perhaps the most dramatic change in ocean chemistry in over 20 million years [248]. Many experiments now demonstrate that ocean acidification may have important consequences for shallow tropical coral reefs which are comprised primarily of calcium carbonate $\left(\mathrm{CaCO}_{3}\right)$ [249-253]. Several studies have demonstrated declines in coral calcification rates across the Great Barrier Reef [254,255] and Arabian Gulf [256] consistent with the expectations of ocean acidification. It has been suggested that reduction in calcification rates may bring about significant changes to coral reef community structure [257-259]. Increased susceptibility to coral bleaching and decreases in productivity has also been demonstrated [260]. Climate projections suggest that all reefs will experience $5 \%$ declines in calcification by the mid-2030s if current levels of fossil fuel emissions continue [261]. Tracking the rate and evolution of ocean acidification in regions of prominent coral reef development is an important aspect to better characterising the threat posed to marine ecosystems.

Ocean chemistry data is typically collected by extensive geochemical cruise surveys [262] and no remote sensing tool is capable of quantifying the components of the carbonic acid system such as the carbon dioxide partial pressure, $\mathrm{pH}$ or carbonate saturation state. However, these complex parameters have been quantified using a mixture of remotely sensed data (e.g., sea surface temperature and sea level pressure), in situ, and modelled environmental parameters linked together through empirical relationships [263]. Satellites supplement in situ data by providing relevant synoptic datasets that can be used to infer changes in ocean chemistry. A practical example is the NOAA Coral Reef Watch experimental Ocean Acidification Product Suite for the Greater Caribbean Region (http://coralreefwatch.noaa.gov/satellite/oa/index.php) that was produced up until 2012. The CRW Ocean Acidification product offered near-real-time estimates of sea surface carbonate chemistry across the Caribbean region, intending to compliment shipboard observations by providing estimates of ocean chemistry on a broader spatial and temporal scale. The underlying model related changes in $\mathrm{CO}_{2}$ gas solubility to differences between $\mathrm{CO}_{2}$ concentrations in the atmosphere and that of the sea surface. Gas solubility can be derived as a function of temperature and salinity where temperature imparts the dominant control. The product used satellite derived SST, modeled sea surface salinity, satellite data assimilated sea-level pressure, and estimates of atmospheric $\mathrm{CO}_{2}$ from flask sample data. The estimated changes in surface ocean chemistry in the Caribbean region since late 1988 to 2009 represent approximately a 3\% decline in aragonite saturation state per decade [263]. This ocean acidification product suite has been updated and is now maintained by NOAA's Acidification, Climate, and Coral Reef Ecosystems Team (ACCRETE) (http://www.coral.noaa.gov/accrete/oaps.html) using satellite data and a data-assimilative hybrid model to map the components of the carbonate system of surface water (Figure 7).

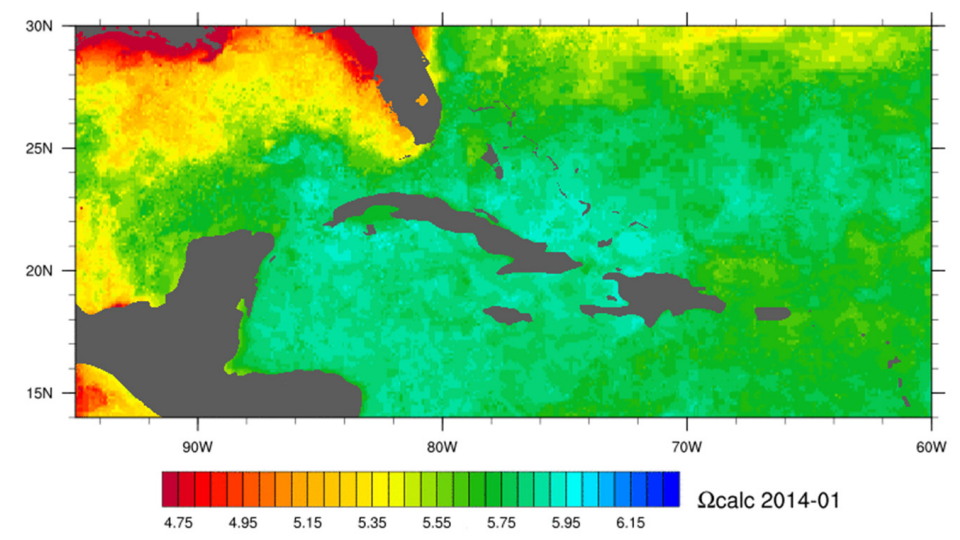

Figure 7. Example of the monthly progression calcite saturation state ( $\Omega$ calc) for the Caribbean in 2014 from the NOAA Acidification, Climate, and Coral Reef Ecosystems Team (ACCRETE) product suite. 


\section{From Remote Sensing to Ecosystem Processes, Parameters and Services}

The previous sections have focused on individual remote sensing products while illustrating a few examples of how multiple data sources can be combined, for example to estimate carbonate chemistry. However, the concepts relevant to management and stakeholders are typically a level above those that can be directly measured, such as ecological processes, ecosystem services, biodiversity, or environmental threat. This final section gives examples of how remote sensed products can be post-processed and combined to give this kind of information, which in remote sensing is often referred to as "Level 4" data: "modelled output or variables derived from multiple measurements" [264]. These kinds of outputs are increasingly required to make remote sensing useful in communicating to stakeholders and policy makers.

\subsection{Mapping Biodiversity}

Maps derived from remotely sensed imagery provide information on the location, areal extent, and nature of habitat patches within a seascape, but they also provide an opportunity to use habitats as a surrogate of other variables of interest within the ecosystem. For example, if some habitats support diverse fish communities and others have more depauperate communities, then a habitat map can be translated into a coarse map of biodiversity.

When considering the efficacy of habitats as surrogates of other variables, there are two critical questions: (1) does the variable of interest vary systematically and consistently among habitats? and (2) how much variation is there within each habitat? The use of habitats as surrogates of biodiversity has a long history in terrestrial ecosystems [265], and is increasingly being used for corals reefs. This is exemplified by recommendations to include every habitat type within networks of marine reserves in order to maximise the chances of including every species [266]. Benthic and fish communities clearly vary among both geomorphological zones and habitat types on reefs (e.g., [267]), but there are surprisingly few studies explicitly addressing the use of maps from remotely sensed imagery as surrogates of biodiversity [268]. In Panama, Andréfouët and Guzman [269] mapped geomorphological zones with Landsat and demonstrated a weak positive correlation between benthic diversity and the number of geomorphological zones in an area, and suggested habitats would be a better surrogate. The study only investigated the number of each species in each zone, rather than analysing multivariate community characteristics, but the results are similar to those of Lindsay et al. [270] who demonstrated that habitats were more effective surrogates for fishes when they were defined at higher resolutions. Dalleau et al. [271] extend this finding to corals and algae, but not commercial invertebrates. Furthermore, data from The Bahamas highlights which combinations of habitats routinely discernible with IKONOS are required to represent $95 \%$ or $100 \%$ of benthic or fish species in a seascape [272]. Detailed habitat maps using CASI have also been used to generate two-dimensional maps of beta diversity (species turnover among habitats) in order to study the environmental factors controlling this important facet of biodiversity [42]. Knudby et al. [273] used a statistical relationship between geomorphic zonation and benthic composition derived from satellite imagery, and field data to determine fish species richness and biomass, demonstrating how satellite imagery can form important input in biodiversity studies (Figure 8).

Rather than simply attempting to use habitat types as surrogates of reef communities, data from habitat maps can be combined with other variables to improve estimates of the abundances of organisms present in any given habitat patch. There is a growing literature on this type of predictive modelling, particularly for reef fishes [274]. For example, in the Caribbean Pittman et al. [275] combined a range of modelling techniques, remotely sensed data, and field observations to demonstrate that fish species richness can be predicted reasonably accurately by bathymetric variance and habitat rugosity. Similarly, in the Indian Ocean, metrics of habitat diversity and bathymetric complexity have been correlated with the species richness and abundance of several guilds and size groupings of fishes [111]. Using a wider range of predictor variables, the approach has also been used to build predictive models for a large array of individual Indo-Pacific fish species [276]. Mellin et al. [73] provide a further example 
for spatial predictions of juvenile fish species richness and abundance, and other studies undertake a similar approach for larger fishes [277]. The approach can also be used for invertebrates. For example, nurseries of the queen conch (Lobatus gigas) occur within seagrass beds, but only in areas with high larval settlement rates, high macroalgal productivity, and low rates of mortality from predation [278].
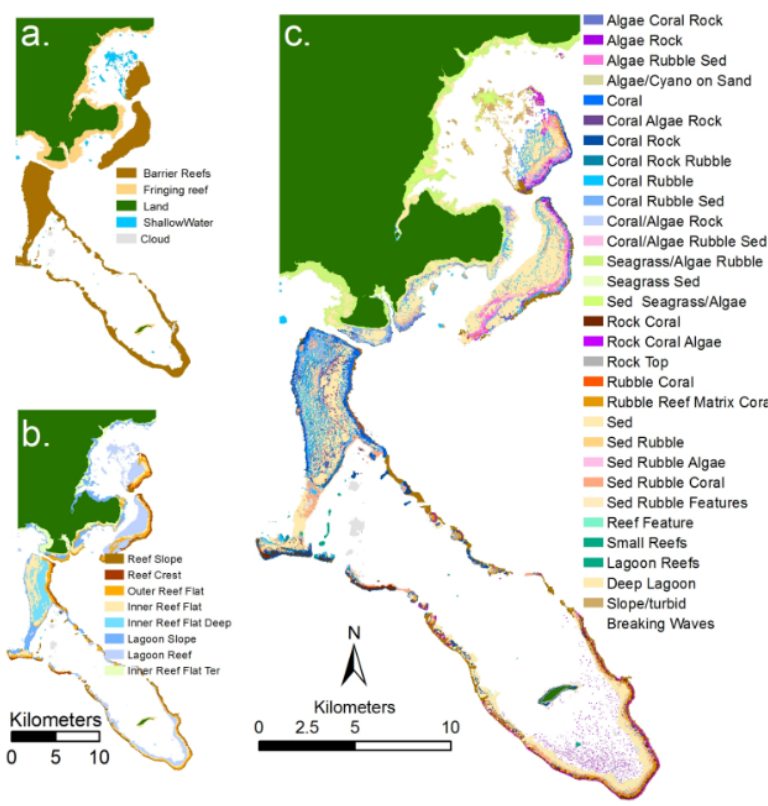

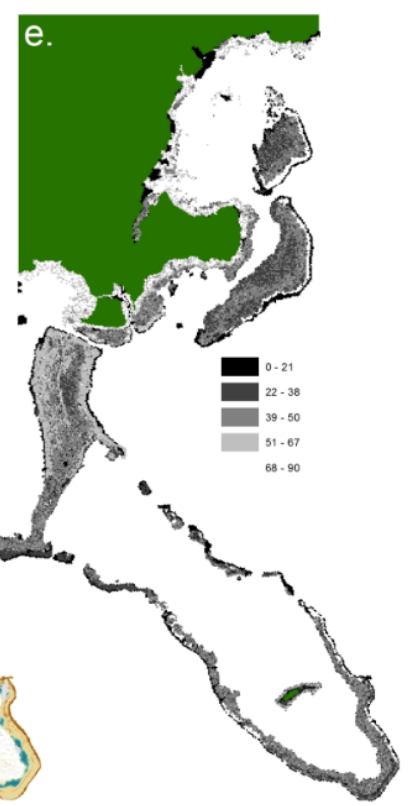

Figure 8. Example of remote sensing based habitat maps used to assist in further assessment of the biodiversity and marine protected area management, Kubulau, Vanu Levu, Fiji. Habitat maps derived from remote sensing imagery: (a) Reef type; (b) geomorphic zone; (c) benthic community; (d) fish biomass based on field data and habitat maps [273], (e) selection frequency for marine park planning targets [65].

By incorporating additional variables, these studies address the important issue of intra-habitat variability when considering habitats as surrogates of species biodiversity. For example, habitat $\mathrm{A}$ found in various patches across a habitat map might be found in different exposure regimes or at different depths and, therefore, each patch may not contain the same benthic or fish communities. The potential for intra-habitat variation in fish communities was demonstrated in The Bahamas, where little significant intra-habitat variability was found among reefs on the same island, but significant inter-island variation occurred in the majority of habitat types [279]. This variation, driven by higher habitat heterogeneity, was highest for the most species rich habitats, and translated into significant variations in fish functional groups and the important ecosystem process of grazing by parrotfishes.

Finally, remotely sensed habitat maps can be used to identify ecotones between habitats that are important features of terrestrial landscapes [280], but have received only scant attention in marine ecosystems (e.g., [281]).

\subsection{Mapping Environments}

Maps of environmental variables derived from remote sensing can be used to classify a marine region according to its physical environment, in the same way that air temperature, rainfall and soil type are commonly used to define areas in land. Temperature and wave energy, for example, are some of the variables that can be measured through satellites and heavily influence pattern and process in marine systems. These factors not only determine the global distribution of reefs [282], but the distribution of reef habitats e.g., [154], reef biodiversity e.g., [42], reef processes e.g., [283], and the impact of disturbance and the recovery of reef ecosystems e.g., [209]. 
Some studies have used synoptic information derived from remote sensing to map marine environments [284,285], providing categorizations with a larger level of detail and homogeneous quality when compared to similar studies that have used expert opinion or in situ databases as inputs e.g., [286]. These studies have used variables such as sea temperature, ocean colour (either a proxy for turbidity or productivity), salinity and currents to define environments both in coastal and open ocean regions.

Information on environments provides an objective framework in which to plan, analyze, and interpret research and/or conservation efforts [284]. In fact, maps of physical environments for Sunda Banda in the Coral Triangle [285] were produced specifically to guide conservation by the World Wide Fund for Nature in the area. The maps can help interpreting research on patterns and function of reef systems. Within the management realm, they can aid assessing the transferability of management approaches and setting realistic expectations for management outcomes, given that areas that belong to similar environments are more likely to respond similarly to management interventions. Additionally, maps of physical environments can help stratifying surveys and facilitating a cost-effective, comprehensive appraisal of a region. In a similar way, the maps could also help stratifying areas for protection to ensure building ecologically representative reserve networks [284].

\subsection{Mapping Ecosystem Processes and Services}

Habitat maps generated from remotely sensed data are clearly useful as a data layer for understanding patterns of biodiversity and then extrapolating these patterns across entire seascapes. However, merging information on habitats and environments from remote sensing can also be used to map ecosystem processes and services. Habitat maps represent just a snapshot of the state of the system that is generated and maintained by ecological processes, and therefore some researchers argue that processes, but not state, should serve as the basis for conservation activities directed to preserve ecosystems [287]. Additionally, remote sensing has been used to map ecosystem services supplies and demands, bridging the gap between conservationists and resource users in promoting sustainability $[288,289]$. For example, maps of habitats, wave exposure and hurricane return times have been used to map the value of coastal protection in Belize [290].

Although Mumby et al. [272] focused on whether patterns of species diversity were effective surrogates for ecosystem processes and services, and vice versa, this work also demonstrated that each process or service varied considerably among habitat types. Therefore, any of the process or service values could be used to parameterise the conversion of a habitat map to a map of, say, macroalgal grazing pressure, vulnerability to hurricane damage, or fisheries value by replacing the habitat label with an indication of whether that process or service is absent or of low, medium, or high importance in that habitat. Indeed, the derived maps of ecosystem processes could be more quantitative by using actual values rather than ordinal scores (see Harborne et al. [291] for a detailed review of the functional value of different Caribbean habitats to a range of ecosystem processes).

These derived maps have a range of potential uses [291], but to date have rarely been utilised in reef research. Recently Arkema et al. [290] used habitat maps and associated ecosystem services for coastal planning in Belize. In Florida, Brock et al. [292] combined various types of imagery with community metabolic rates to investigate large-scale patterns of calcification and primary productivity in a back reef area. Habitat maps have also been used to scale-up carbonate production by fishes in aquaria to estimate total carbonate production across the entire Bahamas [293]. However, perhaps the most exciting applications will come from combining multiple data layers. For example, predictive models of parrotfish densities (and hence grazing pressure), primary productivity, and coral cover have been combined with likely patterns of disturbance (e.g., from hurricanes and bleaching events) and models to map resilience and give insights into the probability of a reef heading on a trajectory towards domination either by coral or by macroalgae [294]. This approach may become increasingly useful for addressing a range of ecological and conservation questions. 


\subsection{Mapping Environmental Threats}

Remote sensing can be used to quantify spatial variation in stressors acting upon coral reefs. Numerous studies have used remote sensing derived layers (such as habitat and land use maps, topography and environmental parameters) as input together with in situ or modeled data to provide a spatially detailed assessment of the threats to the world's coral reefs and cumulative indices indicating overall threats and impacts e.g., [6,295]. While Burke et al. [6] focused on mapping the threats per se, Halpern et al. [295] estimated ecosystem-specific impacts produced by the threats, using a combination of in situ and remotely sensed data. The reliance of these assessments on in situ data, which is frequently unequally sampled and of variable quality in space, is a barrier that limits the use of these products and the inferences that can be drown from them at local scales. Therefore the motivation to develop new methods and increase the use of remote sensing technology to answer large-scale questions remains.

More recently much work has been undertaken to map the specific threats of climate change. For example, rising sea temperatures cause mass coral bleaching and threaten reefs worldwide and maps of variations in thermal stress across the seascape can be used to help manage reefs for climate change. One application of this data is that of marine reserves, which can be targeted to areas of the most benign physical stress to minimise stress overall.

Spatially explicit information on thermal stress from satellite measurements has been used to design networks of reserves to promote the persistence of reefs against bleaching [296-300]. Broadly, the methods differ in the type of data used as input (satellite or modelled), their temporal coverage (one thermal event or multiple ones) and the type of areas targeted for protection (Figure 9). The largest difference among methods resides in the rationale behind which areas to prioritize. While initial research suggested protecting only refugia or areas that have been least impacted by thermal stress [296,297,300,301], more recent research also prioritizes areas of potentially high coral acclimation and adaptation, which could have a vital role increasing the survival of corals [298,299]. Different variables have been used as proxies for coral acclimation, such as higher summer temperatures [298] or the rate of seasonal warming from spring to summer [299], reflecting increasing knowledge on the role of thermal stress in coral acclimation to bleaching. The integration of additional considerations including the spatial distribution of reef sites, current levels of reef health and biodiversity, population connectivity and socio-economic constraints requires a more complex approach to reserve-design using site-selection algorithms such as Marxan [296,298].

\section{Summary and Conclusions}

With respect to measuring "reef health" the current status of satellite remote sensing is that it can be used to assess the environment of the reefs and map the location of reef habitats and communities but not to measure the health of the system directly. While airborne hyperspectral sensors have been used to distinguish the levels of coral mortality in isolated studies, it is presently unknown whether future satellite hyperspectral sensors would offer such discriminating power and the applicability to reefs in general. Satellite monitoring of sea surface temperature is very effective at predicting where and when coral bleaching events will take place and recent developments indicate that these predictions can be improved by considering other factors such as light levels. Bleaching predictions from remotely sensed data are already used routinely by many coral reef management agencies. However, what is less certain, at present, is how best to predict the outcome of such events; i.e., the extent to which the corals recover or die. This is a more serious management problem and solving it will require further research. 


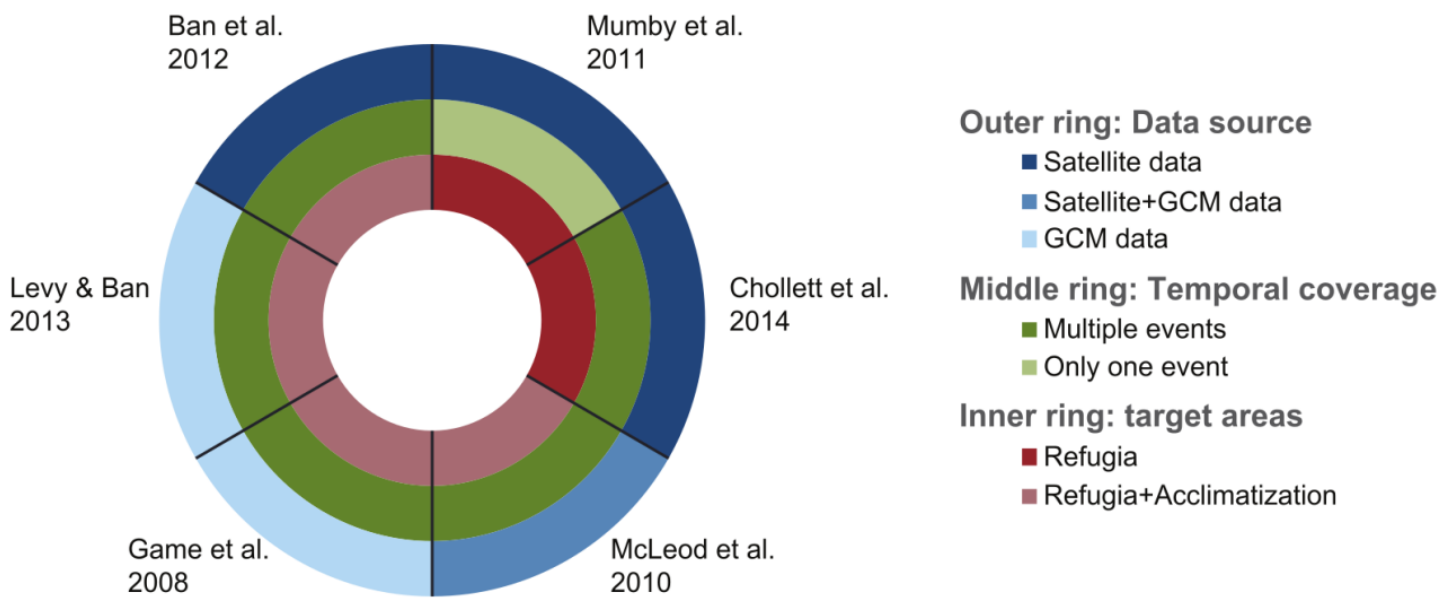

Figure 9. Comparison of methods available to prioritise areas for conservation in a climate change context. Contrasts in terms of the source of the data used (blue ring), the temporal coverage of the analyses (green ring) and the type of areas targeted for protection (red ring) (source [299], references cited clockwise starting at Mumby et al., 2011 are [296-300]).

On a purely technological level, capability for remote sensing of coral reefs continues to advance in line with sensor technology. The main advances in the last five years have been in terms of spatial resolution: habitat mapping and bathymetry now benefits from a variety of sub 2-m pixel multispectral satellite data sources, and SST products such as NOAA's Coral Reef Watch products have been upgraded from $50 \mathrm{~km}$ to $5 \mathrm{~km}$ resolution. Conversely, the benefits of hyperspectral data for reef mapping, although much discussed in the literature, have yet to be realised through satellite applications-primarily because the recent technology drive has been for high spatial resolution multispectral data. Algorithm development also continues to improve capability, examples being object-orientated classification, bathymetry from radiative transfer model inversion and new methods for determining optical properties of the water in shallow coastal areas. However fundamental limitations exist inherently in what can be deduced by optical remote sensing of complex multi-parameter systems; hence the introduction of uncertainty propagation into algorithms is an increasingly important aspect for future algorithm development. When the fundamental limitations are reached, it is important to quantify and make transparent those limitations directly in the delivered products, to build rather than undermine user confidence.

While incremental improvements due to technology and algorithms are to be expected, the real scope for substantial advances is in combining of multiple data sources from remote sensing, field data and modelling. Various studies have combined remote sensing habitat maps, environmental data and models toward ecological characterisation and MPA design; the challenge is to turn these proof-of concept studies into operational approaches that can be routinely applied. In this context remote sensing is a complementary approach; it does not aim to replace in situ surveys but provides a different kind of information that is required for some applications. To improve uptake of remote sensing data for coral reef management it is necessary first to show that data sources in combination can contribute more than the sum of the parts, but also to develop the infrastructure that make this data synthesis straightforward and repeatable.

Acknowledgments: This paper was initiated as part of the World Bank/GEF Coral Reef Targeted Research and Capacity Building Program. The authors thank Andy Hooten and Marea Hatziolos for making this collaboration possible. I. Chollett is funded by the Summit Foundation and this is manuscript contribution number 1021 from the Smithsonian Marine Station at Fort Pierce, Florida. A. Harborne was funded by the Natural Environment Research Council, UK (fellowship NE/F015704/1) and the Australian Research Council (fellowship DE120102459). The contents in this manuscript are solely the opinions of the authors and do not constitute a statement of policy, decision or position on behalf of NOAA or the U.S. Government.

Conflicts of Interest: The authors declare no conflict of interest. 


\section{References}

1. Bellwood, D.R.; Hughes, T.P.; Folke, C.; Nystrom, M. Confronting the coral reef crisis. Nature 2004, 429, 827-833. [CrossRef] [PubMed]

2. Gardner, T.A.; Cote, I.M.; Gill, J.A.; Grant, A.; Watkinson, A.R. Long-term region-wide declines in Caribbean corals. Science 2003, 301, 958-960. [CrossRef] [PubMed]

3. Pandolfi, J.M.; Bradbury, R.H.; Sala, E.; Hughes, T.P.; Bjorndal, K.A.; Cooke, R.G.; McArdle, D.; McClenachan, L.; Newman, M.J.H.; Paredes, G.; et al. Global trajectories of the long-term decline of coral reef ecosystems. Science 2003, 301, 955-958. [CrossRef] [PubMed]

4. Pennisi, E. Survey confirms coral reefs are in peril. Science 2002, 297, 1622b-1623b. [CrossRef] [PubMed]

5. Wilkinson, C. Status of Coral Reefs of the World; Global Coral Reef Monitoring Network and Reef and Rainforest Research Centre: Townsville, QLD, Australia, 2008; p. 296.

6. Burke, L.; Reytar, K.; Spalding, M.; Perry, A. Reefs at Risk Revisited; World Resources Institute: Washington, DC, USA, 2011; p. 114.

7. Mora, C. A clear human footprint in the coral reefs of the Caribbean. Proc. R. Soc. B-Biol. Sci. 2008, 275, 767-773. [CrossRef] [PubMed]

8. Baker, A.C.; Glynn, P.W.; Riegl, B. Climate change and coral reef bleaching: An ecological assessment of long-term impacts, recovery trends and future outlook. Estuar. Coast. Shelf Sci. 2008, 80, 435-471. [CrossRef]

9. Hoegh-Guldberg, O.; Mumby, P.J.; Hooten, A.J.; Steneck, R.S.; Greenfield, P.; Gomez, E.; Harvell, C.D.; Sale, P.F.; Edwards, A.J.; Caldeira, K.; et al. Coral reefs under rapid climate change and ocean acidification. Science 2007, 318, 1737-1742. [CrossRef] [PubMed]

10. Hodgson, G. Reef Check: The first step in community-based management. Bull. Mar. Sci. 2001, 69, 861-868.

11. Obura, D.O.; Tamelander, J.; Linden, O. Ten Years After Bleaching_Facing the Consequences of Climate Change in the Indian Ocean; CORDIO Status Report 2008; CORDIO (Coastal Oceans Research and Development, Indian Ocean)/Sida-SAREC: Mombasa, Kenya, 2008; p. 493.

12. CARICOMP. The Caribbean coastal marine productivity program (CARICOMP). Bull. Mar. Sci. 1999, 69, 819-829.

13. Wilkinson, C. Status of Coral Reefs of the World; Australian Institute of Marine Science: Townsville, QLD, Australia, 1998; p. 184.

14. Wilkinson, C. Status of Coral Reefs of the World; Australian Institute of Marine Science: Townsville, QLD, Australia, 2000; p. 363.

15. Wilkinson, C. Status of Coral Reefs of the World; Australian Institute of Marine Science: Townsville, QLD, Australia, 2002; p. 378.

16. Wilkinson, C. Status of Coral Reefs of the World; Australian Institute of Marine Science: Townsville, QLD, Australia, 2004; p. 301.

17. Bruno, J.F.; Selig, E.R. Regional decline of coral cover in the Indo-Pacific: Timing, extent, and subregional comparisons. PLoS ONE 2007, 2, e711. [CrossRef] [PubMed]

18. Jackson, J.B.C.; Donovan, M.K.; Cramer, K.L.; Lam, V.V. Status and Trends of Caribbean Coral Reefs: 1970-2012; Global Coral Reef Monitoring Network, IUCN: Gland, Switzerland, 2014.

19. Edmunds, P.J.; Bruno, J.F. The importance of sampling scale in ecology: Kilometer-wide variation in coral reef communities. Mar. Ecol. Prog. Ser. 1996, 143, 165-171. [CrossRef]

20. Hughes, T.P.; Baird, A.H.; Dinsdale, E.A.; Moltschaniwskij, N.A.; Pratchett, M.S.; Tanner, J.E.; Willis, B.L. Patterns of recruitment and abundance of corals along the Great Barrier Reef. Nature 1999, 397, 59-63. [CrossRef]

21. Downs, C.A.; Woodley, C.M.; Richmond, R.H.; Lanning, L.L.; Owen, R. Shifting the paradigm of coral-reef "health" assessment. Mar. Pollut. Bull. 2005, 51, 486-494. [CrossRef] [PubMed]

22. Risk, M.J. Paradise lost: How marine science failed the world's coral reefs. Mar. Freshw. Res. 1999, 50, 831-837. [CrossRef]

23. Anon. Workshop of GCRMN for the Wider Caribbean: Review, Improve and Revitalize the Network and the Nodes for More Effective Coral Reef Monitoring and Data Management Curaçao, 6th-8th of August 2014. Available online: http://www.icriforum.org/node/1567 (accessed on 18 September 2015).

24. De'ath, G.; Fabricius, K.E.; Sweatman, H.; Puotinen, M. The 27-year decline of coral cover on the Great Barrier Reef and its causes. PNAS 2012, 109, 17995-17999. [CrossRef] [PubMed] 
25. González-Rivero, M.; Bongaerts, P.; Beijbom, O.; Pizarro, O.; Friedman, A.; Rodriguez-Ramirez, A.; Upcroft, B.; Laffoley, D.; Kline, D.; Vevers, R.; et al. The Catlin Seaview Survey-Kilometre-scale seascape assessment, and monitoring of coral reef ecosystems. Aquat. Conserv. Mar. Freshw. Ecosyst. 2014, 24, 184-198. [CrossRef]

26. Beijbom, O.; Edmunds, P.J.; Kline, D.I.; Mitchell, B.G.; Kriegman, D. Automated Annotation of Coral Reef Survey Images. In Proceedings of the IEEE Conference on Computer Vision (CVPR), Providence, RI, USA, 16-21 June 2012.

27. Jupiter, S.; Roelfsema, C.M.; Phinn, S.R. Science and management. In Coral Reef Remote Sensing; Goodman, J.A., Phinn, S.R., Purkis, S., Eds.; Springer: Berlin, Germany, 2013; pp. 403-427.

28. Mumby, P.J.; Green, E.P.; Edwards, A.J.; Clark, C.D. The cost-effectiveness of remote sensing for tropical coastal resources assessment and management. J. Environ. Manag. 1999, 55, 157-166. [CrossRef]

29. Mumby, P.J.; Hedley, J.D.; Chisholm, J.R.M.; Clark, C.D.; Ripley, H.; Jaubert, J. The cover of living and dead corals from airborne remote sensing. Coral Reefs 2004, 23, 171-183. [CrossRef]

30. Green, E.P.; Mumby, P.J.; Edwards, A.J.; Clark, C.D. A review of remote sensing for the assessment and management of tropical coastal resources. Coast. Manag. 1996, 24, 1-40. [CrossRef]

31. Hu, C.M.; Hackett, K.E.; Callahan, M.K.; Andrefouet, S.; Wheaton, J.L.J.; Porter, J.W.; Muller-Karger, F.E. The 2002 ocean color anomaly in the Florida Bight: A cause of local coral reef decline? Geophys. Res. Lett. 2003. [CrossRef]

32. Malthus, T.J.; Mumby, P.J. Remote sensing of the coastal zone: An overview and priorities for future research. Int. J. Remote Sens. 2003, 24, 2805-2815. [CrossRef]

33. Eakin, C.M.; Nim, C.J.; Brainard, R.E.; Aubrecht, C.; Elvidge, C.; Gledhill, D.K.; Muller-Karger, F.; Mumby, P.J.; Skirving, W.J.; Strong, A.E.; et al. Monitoring coral reefs from space. Oceanography 2010, 23, 118-133. [CrossRef]

34. Mumby, P.J.; Skirving, W.; Strong, A.E.; Hardy, J.T.; LeDrew, E.F.; Hochberg, E.J.; Stumpf, R.P.; David, L.T. Remote sensing of coral reefs and their physical environment. Mar. Pollut. Bull. 2004, 48, 219-228. [CrossRef] [PubMed]

35. Phinn, S.R.; Hochberg, E.; Roelfsema, C.M. Airborne photography, multispectral and hyperspectral remote sensing on coral reefs. In Coral Reef Remote Sensing; Goodman, J.A., Phinn, S.R., Purkis, S., Eds.; Springer: Berlin, Germany, 2013; pp. 3-25.

36. Phinn, S.R.; Roelfsema, C.M.; Stumpf, R. Remote sensing: Discerning the promise from the reality. In Integrating and Applying Science: A Handbook for Effective Coastal Ecosystem Assessment; Longstaff, B.J., Carruthers, T.J.B., Dennison, W.C., Lookingbill, T.R., Hawkey, J.M., Thomas, J.E., Wicks, E.C., Woerner, J., Eds.; IAN Press: Cambridge, MD, USA, 2010.

37. Ball, I.R.; Possingham, H.P.; Watts, M. Marxan and relatives: Software for spatial conservation prioritisation. In Spatial Conservation Prioritisation: Quantitative Methods and Computational Tools; Moilanen, A., Wilson, K.A., Possingham, H.P., Eds.; Oxford University Press: Oxford, UK, 2009; pp. 185-195.

38. Green, P.E.; Mumby, P.J.; Edwards, A.J.; Clark, C.D. Remote Sensing Handbook for Tropical Coastal Management; UNESCO: Paris, France, 2000; p. 316.

39. Andréfouët, S.; Hochberg, E.J.; Chevillon, C.; Muller-Karger, F.E.; Brock, J.C.; Hu, C. Multi-scale remote sensing of coral reefs. In Remote Sensing of Coastal Aquatic Environments; Har, R.L., Miller, X., Del Castillo, C.E., Mckee, B.A., Eds.; Springer: Dordrecht, the Netherlands, 2005; pp. 297-315.

40. Benfield, S.L.; Guzman, H.M.; Mair, J.M.; Young, J.A.T. Mapping the distribution of coral reefs and associated sublittoral habitats in Pacific Panama: A comparison of optical satellite sensors and classification methodologies. Int. J. Remote Sens. 2007, 23, 5047-5070. [CrossRef]

41. Capolsini, P.; Andréfouët, S.; Rion, C.; Payri, C. A comparison of Landsat ETM+, SPOT HRV, Ikonos, ASTER, and airborne MASTER data for coral reef habitat mapping in South Pacific islands. Can. J. Remote Sens. 2007, 23, 87-200. [CrossRef]

42. Harborne, A.R.; Mumby, P.J.; Zychaluk, K.; Hedley, J.D.; Blackwell, P.G. Modeling the beta diversity of coral reefs. Ecology 2006, 87, 2871-2881. [CrossRef]

43. Goodman, J.A.; Ustin, S.L. Classification of benthic composition in a coral reef environment using spectral unmixing. J. Appl. Remote Sens. 2007, 1, 011501. 
44. Hamylton, S. Estimating the coverage of coral reef benthic communities from airborne hy-perspectral remote sensing data: Multiple discriminant function analysis and linear spectral unmixing. Int. J. Remote Sens. 2011, 32, 9673-9690. [CrossRef]

45. Andréfouët, S.; Muller-Karger, F.E.; Robinson, J.A.; Kranenburg., C.J.; Torres-Pulliza, D.; Spraggins, S.; Murch, B. Global assessment of modern coral reef extent and diversity for regional science and management applications: A view from space. In Proceedings of the 10th International Coral Reef Symposium, Okinawa, Japan, 28 June-2 July 2004.

46. Hedley, J.D.; Roelfsema, C.; Koetz, B.; Phinn, S. Capability of the Sentinel 2 mission for tropical coral reef mapping and coral bleaching detection. Remote Sens. Environ. 2012, 120, 145-155. [CrossRef]

47. Andréfouët, S.; Riegl, B. Remote sensing: A key tool for interdisciplinary assessment of coral reef processes. Coral Reefs 2004, 23, 1-4. [CrossRef]

48. Diaz, R.J.; Solan, M.; Valente, R.M. A review of approaches for classifying benthic habitats and evaluating habitat quality. J. Environ. Manag. 2004, 73, 165-181. [CrossRef] [PubMed]

49. Mumby, P.J.; Edwards, A.J. Mapping marine environments with IKONOS imagery: Enhanced spatial resolution can deliver greater thematic accuracy. Remote Sens. Environ. 2002, 82, 248-257. [CrossRef]

50. Johansen, K.; Roelfsema, C.; Phinn, S. High spatial resolution remote sensing for environmental monitoring and management. J. Spat. Sci. 2008, 53, 43-47. [CrossRef]

51. Klemas, V.V. Coastal and environmental remote sensing from unmanned aerial vehicles: An overview. J. Coast. Res. 2015, 31, 1260-1267. [CrossRef]

52. Kobryn, H.T.; Wouters, K.; Beckley, L.E.; Heege, T. Ningaloo reef: Shallow marine habitats mapped using a hyperspectral sensor. PLOS ONE 2013, 8, e70105. [CrossRef] [PubMed]

53. Roelfsema, C.M.; Phinn, S.R.; Jupiter, S.; Comley, J.; Albert, S. Mapping coral reefs at reef to reef-system scales (10-600 $\left.\mathrm{km}^{2}\right)$ using OBIA driven ecological and geomorphic principles. Int. J. Remote Sens. 2013, 34, 6367-6388. [CrossRef]

54. Elvidge, C.D.; Dietz, J.B.; Berkelmans, R.; Andréfouët, S.; Skirving, W.; Strong, A.E.; Tuttle, B.T. Satellite observation of Keppel Islands (Great Barrier Reef) 2002 coral bleaching using IKONOS data. Coral Reefs 2004, 23, 123-132. [CrossRef]

55. Riegl, B.M.; Purkis, S.J. Detection of shallow subtidal corals from IKONOS satellite and QTC View (50, 200 kHz) single-beam sonar data (Arabian Gulf; Dubai, UAE). Remote Sens. Environ. 2005, 95, 96-114. [CrossRef]

56. Hedley, J.D.; Roelfsema, C.M.; Phinn, S.R.; Mumby, P.J. Environmental and sensor limitations in optical remote sensing of coral reefs: Implications for monitoring and sensor design. Remote Sens. 2012, 4, 271-302. [CrossRef]

57. Purkis, S.J.; Pasterkamp, R. Integrating in-situ reef-top reflectance spectra with Landsat TM imagery to aid shallow-tropical benthic habitat mapping. Coral Reefs 2004, 23, 5-20. [CrossRef]

58. Hedley, J.D.; Harborne, A.R.; Mumby, P.J. Simple and robust removal of sun glint for mapping shallow-water benthos. Int. J. Remote Sens. 2005, 26, 2107-2112. [CrossRef]

59. Kay, S.; Hedley, J.D.; Lavender, S. Sun glint correction of high and low spatial resolution images of aquatic scenes: A review of methods for visible and near-infrared wavelengths. Remote Sens. 2009, 1, 697-730. [CrossRef]

60. Mumby, P.J.; Clark, C.D.; Green, E.P.; Edwards, A.J. Benefits of water column correction and contextual editing for mapping coral reefs. Int. J. Remote Sens. 1998, 19, 203-210. [CrossRef]

61. Zoffoli, M.L.; Frouin, R.; Kampel, M. Water column correction for coral reef studies by remote sensing. Sensors 2014, 14, 16881-16931. [CrossRef] [PubMed]

62. Purkis, S.J. A "reef-up" approach to classifying coral habitats from IKONOS imagery. IEEE Trans. Geosci. Remote Sens. 2005, 43, 1375-1390. [CrossRef]

63. Lim, A.; Hedley, J.D.; LeDrew, E.; Mumby, P.J.; Roelfsema, C. The effects of ecologically determined spatial complexity on the classification accuracy of simulated coral reef images. Remote Sens. Environ. 2009, 113, 965-978. [CrossRef]

64. Mumby, P.J.; Green, E.P.; Edwards, A.J.; Clark, C.D. Coral reef habitat-mapping: How much detail can remote sensing provide? Mar. Biol. 1997, 130, 193-202. [CrossRef]

65. Tulloch, V.J.; Possingham, H.P.; Jupiter, S.D.; Roelfsema, C.; Tulloch, A.I.T.; Klein, C.J. Incorporating uncertainty associated with habitat data in marine reserve design. Biol. Conserv. 2013, 162, 41-51. [CrossRef] 
66. Roelfsema, C.M.; Phinn, S.R. Validation. In Coral Reef Remote Sensing: A Guide for Multi-level Sensing Mapping and Assessment; Goodman, J., Purkis, S., Phinn, S.R., Eds.; Springer: Berlin, German, 2013; pp. 375-365.

67. Stehman, S.V.; Czaplewski, R.L. Design and analysis for thematic map accuracy assessment: Fundamental principles. Remote Sens. Environ. 1998, 64, 331-344. [CrossRef]

68. Congalton, R.G.; Green, K. Assessing the Accuracy of Remotely Sensed Data: Principles and Practices; Lewis Publishers: Boca Rotan, FL, USA, 1999; p. 137.

69. Roelfsema, C.M.; Phinn, S.R. Calibration and validation of coral reef benthic community maps: integration of field data with high spatial resolution multi spectral satellite imagery. J. Appl. Remote Sens. 2010, 4, 043527. [CrossRef]

70. Lauer, M.; Aswani, S. Integrating indigenous ecological knowledge and multi-spectral image classification for marine habitat mapping in Oceania. Ocean Coast. Manag. 2008, 51, 495-504. [CrossRef]

71. Bouvet, G.; Ferraris, J.; Andréfouët, S. Evaluation of large-scale unsupervised classification of New Caledonia reef ecosystems using Landsat 7 ETM+ imagery. Oceanol. Acta 2003, 26, 281-290. [CrossRef]

72. Mishra, D.R.; Narumalani, S.; Rundquist, D.; Lawson, M. High-resolution ocean color remote sensing of Benthic habitats: A case study at the Roatan Island, Honduras. IEEE Trans. Geosci. Remote Sens. 2005, 43, 1592-1604. [CrossRef]

73. Mellin, C.; Andréfouët, S.; Ponton, D. Spatial predictability of juvenile fish species richness and abundance in a coral reef environment. Coral Reefs 2007, 26, 895-907. [CrossRef]

74. Bainbridge, S.J.; Reichelt, R.E. An assessment of ground truth methods for coral reef remote sensing data. In Proceedings of the 6th International Coral Reef Symposium, Townsville, Australia, 8-12 August 1988; pp. 439-444.

75. Purkis, S.J.; Kenter, A.M.; Oikonomou, E.K.; Robinson, I.S. High-resolution ground verification, cluster analysis and optical model of reef substrate coverage on Landsat TM imagery (Red Sea, Egypt). Int. J. Remote Sens. 2002, 23, 1677-1698. [CrossRef]

76. Bello-Pineda, J.; Liceaga-Correa, M.A.; Hernandez, H.; Ponce-Hernandez, R. Using aerial video to train the supervised classification of Landsat TM imagery for coral reef habitats mapping. Environ. Monit. Assess. 2005, 105, 145-164. [CrossRef] [PubMed]

77. Joyce, K.E.; Phinn, S.R.; Roelfsema, C.M.; Neil, D.T.; Dennison, W.C. Combining Landsat ETM plus and Reef Check classifications for mapping coral reefs: A critical assessment from the southern Great Barrier Reef, Australia. Coral Reefs 2004, 23, 21-25. [CrossRef]

78. Mumby, P.J.; Harborne, A.R. Development of a systematic classification scheme of marine habitats to facilitate regional management and mapping of Caribbean coral reefs. Biol. Conserv. 1999, 88, 155-163. [CrossRef]

79. Aswani, S.; Lauer, M. Benthic mapping using local aerial photo interpretation and resident taxa inventories for designing marine protected areas. Environ. Conserv. 2006, 33, 263-273. [CrossRef]

80. Cuevas-Jimenez, A.; Ardisson, P.L. Mapping shallow coral reefs by colour aerial photography. Int. J. Remote Sens. 2002, 23, 3697-3712. [CrossRef]

81. Mishra, D.; Narumalani, S.; Rundquist, D.; Lawson, M. Benthic habitat mapping in tropical marine environments using QuickBird multispectral data. Photogramm. Eng. Remote Sens. 2006, 72, 1037-1048. [CrossRef]

82. Hedley, J.D.; Mumby, P.J. Biological and remote sensing perspectives of pigmentation in coral reef organisms. Adv. Mar. Biol. 2002, 43, 277-317. [PubMed]

83. Hochberg, E.J.; Atkinson, M.J.; Andréfouët, S. Spectral reflectance of coral reef bottom-types worldwide and implications for coral reef remote sensing. Remote Sens. Environ. 2003, 85, 159-173. [CrossRef]

84. Blaschke, T.; Lang, S.; Hay, G.J. Object Based Image Analysis; Springer: Berlin, German, 2008; p. 836.

85. Blaschke, T. Object based image analysis for remote sensing. ISPRS J. Photogramm. Remote Sens. 2010, 65, 2-16. [CrossRef]

86. Lathrop, R.G.; Montesano, P.; Haag, S. A multi-scale segmentation approach to mapping seagrass habitats using airborne digital camera imagery. Photogram. Eng. Remote Sens. 2006, 72, 665-675. [CrossRef]

87. Phinn, S.R.; Roelfsema, C.M.; Mumby, P.J. Multi-scale image segmentation for mapping geomorphic and ecological zones on coral reefs. Int. J. Remote Sens. 2012, 33, 3768-3797. [CrossRef]

88. Roelfsema, C.M.; Lyons, M.; Kovacs, E.M.; Maxwell, P.; Saunders, M.I.; Samper-Villarreal, J.; Phinn, S.R. Multi-temporal mapping of seagrass cover, species and biomass: A semi-automated object based image analysis approach. Remote Sens. Environ. 2014, 150, 172-187. [CrossRef] 
89. Zhang, C.; Selch, D.; Xie, Z.; Roberts, C.; Cooper, H.; Chen, G. Object-based benthic habitat mapping in the Florida Keys from hyperspectral imagery. Estuar. Coast. Shelf Sci. 2013, 134, 88-97. [CrossRef]

90. Zhang, C. Applying data fusion techniques for benthic habitat mapping and monitoring in a coral reef ecosystem. ISPRS J. Photogram. Remote Sens. 2015, 104, 213-223. [CrossRef]

91. Hedley, J.D.; Roelfsema, C.; Phinn, S.R. Efficient radiative transfer model inversion for remote sensing applications. Remote Sens. Environ. 2009, 113, 2527-2532. [CrossRef]

92. Joyce, K.E.; Phinn, S.R.; Roelfsema, C.M. Live coral cover index testing and application with hyperspectral airborne image data. Remote Sens. 2013, 5, 6116-6137. [CrossRef]

93. Mumby, P.J.; Green, E.P.; Edwards, A.J.; Clark, C.D. Measurement of seagrass standing crop using satellite and digital airborne remote sensing. Mar. Ecol. Prog. Ser. 1997, 159, 51-60. [CrossRef]

94. Phinn, S.; Roelfsema, C.; Dekker, A.; Brando, V.; Anstee, J. Mapping seagrass species, cover and biomass in shallow waters: An assessment of satellite multi-spectral and airborne hyper-spectral imaging systems in Moreton Bay (Australia). Remote Sens. Environ. 2008, 112, 3413-3425. [CrossRef]

95. Lyons, M.; Roelfsema, C.M.; Kovacs, E.; Samper-Villarreal, J.; Saunders, M.I.; Maxwell, P.; Phinn, S.R. Rapid monitoring of seagrass biomass using a simple linear modelling approach, in the field and from space. Mar. Ecol. Prog. Ser. 2015, 530, 1-14. [CrossRef]

96. Enríquez, S.; Mendez, E.R.; Iglesias-Prieto, R. Multiple scattering on coral skeletons enhances light absorption by symbiotic algae. Limnol. Oceanogr. 2005, 50, 1025-1032. [CrossRef]

97. Andréfouët, S.; Berkelmans, R.; Odriozola, L.; Done, T.; Oliver, J.; Muller-Karger, F. Choosing the appropriate spatial resolution for monitoring coral bleaching events using remote sensing. Coral Reefs 2002, 21, 147-154.

98. Berkelmans, R.; Oliver, J.K. Large-scale bleaching of corals on the Great Barrier Reef. Coral Reefs 1999, 18, 55-60. [CrossRef]

99. Berkelmans, R.; De'ath, G.; Kininmonth, S.; Skirving, W. A comparison of the 1998 and 2002 coral bleaching events on the Great Barrier Reef: Spatial correlation, patterns, and predictions. Coral Reefs 2004, 23, 74-83. [CrossRef]

100. Yamano, H.; Tamura, M. Detection limits of coral reef bleaching by satellite remote sensing: Simulation and data analysis. Remote Sens. Environ. 2004, 90, 86-103. [CrossRef]

101. Rowlands, G.P.; Purkis, S.J.; Riegl, B.M. The 2005 coral-bleaching event, Roatan (Honduras): Use of pseudo-invariant features (PIFs) in satellite assessments. J. Spat. Sci. 2008, 53, 99-112. [CrossRef]

102. Palandro, D.A.; Andréfouët, S.; Hu, C.; Hallock, P.; Muller-Karger, F.; Dustan, P.; Callahan, M.K.; Kranenburg, C.; Beaver, C.R. Quantification of two decades of shallow-water coral reef habitat decline in the Florida Keys National Marine Sanctuary using Landsat data (1984-2002). Remote Sens. Environ. 2008, 112, 3388-3399. [CrossRef]

103. Knudby, A.; Newman, C.; Shaghude, Y.; Muhando, C. Simple and effective monitoring of historic changes in nearshore environments using the free archive of Landsat imagery. Int. J. Appl. Earth Obs. Geoinform. 2010, 12S, S116-S122. [CrossRef]

104. Lyons, M.B.; Roelfsema, C.M.; Phinn, S.R. Towards understanding temporal and spatial dynamics of seagrass landscapes using time-series remote sensing. Estuar. Coast. Shelf Sci. 2013, 120, 42-53. [CrossRef]

105. Andréfouët, S.; Muller-Karger, F.E.; Hochberg, E.J.; Hu, C.; Carder, K.L. Change detection in shallow coral reef environments using Landsat 7/ETM+ data. Remote Sens. Environ. 2001, 78, 150-162. [CrossRef]

106. Roelfsema, C.M.; Kovacs, E.; Phinn, S.R.; Lyons, M.; Saunders, M.; Maxwell, P. Challenges of remote sensing for quantifying changes in large complex seagrass environments. Estuar. Coast. Shelf Sci. 2013, 133, 161-171. [CrossRef]

107. Heron, S.F.; Skirving, W.J. Satellite bathymetry use in numerical models of ocean thermal stress. La Revista Gayana 2004, 68, 284-288. [CrossRef]

108. Foster-Smith, R.L.; Davies, J.; Sotheran, I.; Walton, R. Is the RoxAnn2 ground discrimination system a useful tool for remote sensing and mapping of subtidal benthic marine habitats? In Proceedings of the 1998 Canadian Hydrographic Conference: Turning data into dollars, Victoria, Canada, 10-12 March 1998.

109. White, W.H.; Harborne, A.R.; Sotheran, I.S.; Walton, R.; Foster-Smith, R.L. Using an acoustic ground discrimination system to map coral reef benthic classes. Int. J. Remote Sens. 2003, 24, 2641-2660. [CrossRef]

110. Collier, J.S.; Humber, S.R. Time-lapse side-scan sonar imaging of bleached coral reefs: A case study from the Seychelles. Remote Sens. Environ. 2007, 108, 339-356. [CrossRef] 
111. Purkis, S.J.; Graham, N.A.J.; Riegl, B.M. Predictability of reef fish diversity and abundance using remote sensing data in Diego Garcia (Chagos Archipelago). Coral Reefs 2008, 27, 167-178. [CrossRef]

112. Jordan, L.K.B.; Gilliam, D.S.; Spieler, R.E. Reef fish assemblage structure affected by small-scale size and spatial variations of artificial patch reefs. J. Exp. Mar. Biol. Ecol. 2005, 326, 170-186. [CrossRef]

113. Kuffner, I.B.; Brock, J.C.; Grober-Dunsmore, R.; Bonito, V.E.; Hickey, T.D.; Wright, C.W. Relationships between reef fish communities and remotely sensed rugosity measurements in Biscayne National Park, Florida, USA. Environ. Biol. Fish 2007, 78, 71-82. [CrossRef]

114. Bejarano, S.; Mumby, P.J.; Sotheran, I. Predicting structural complexity of reefs and fish abundance using acoustic remote sensing (RoxAnn). Mar. Biol. 2011, 158, 489-504. [CrossRef]

115. Gratwicke, B.; Speight, M.R. The relationship between fish species richness, abundance and habitat complexity in a range of shallow tropical marine habitats. J. Fish Biol. 2005, 66, 650-667. [CrossRef]

116. Karpouzli, E.; Malthus, T. Integrating dual frequency side scan sonar and high spatial resolution satellite imagery for monitoring coral reef benthic communities. In Proceedings of the 2007. IGARSS 2007 IEEE International on Geoscience and Remote Sensing Symposium, Barcelona, Spain, 23-28 July 2007.

117. Bejarano, S.; Mumby, P.J.; Hedley, J.D.; Sotheran, I. Combining optical and acoustic data to enhance the accuracy of coral reef habitat maps. Remote Sens. Environ. 2009, 114, 2768-2778. [CrossRef]

118. Walker, B.K.; Riegl, B.; Dodge, R.E. Mapping coral reef habitats in southeast Florida using a combined technique approach. J. Coast. Res. 2008, 5, 1138-1150. [CrossRef]

119. Brock, J.; Wright, C.; Clayton, T.; Nayegandhi, A. LIDAR optical rugosity of coral reefs in Biscayne National Park, Florida. Coral Reefs 2004, 23, 48-59. [CrossRef]

120. Brock, J.C.; Wright, C.W.; Kuffner, I.B.; Hernandez, R.; Thompson, P. Airborne LiDAR sensing of massive stony coral colonies on patch reefs in the northern Florida reef tract. Remote Sens. Environ. 2006, 104, 31-42. [CrossRef]

121. Walker, B.K.; Jordan, L.K.B.; Spieler, R.E. Relationship of reef fish assemblages and topographic complexity on southeastern Florida coral reef habitats. J. Coast. Res. 2009, 53, 39-48. [CrossRef]

122. Costa, B.M.; Battista, T.A.; Pittman, S.J. Comparative evaluation of airborne LiDAR and ship-based multibeam SoNAR bathymetry and intensity for mapping coral reef ecosystems. Remote Sens. Environ. 2009, 113, 1082-1100. [CrossRef]

123. Lyzenga, D.R. Passive remote sensing techniques for mapping water depth and bottom features. Appl. Opt. 1978, 17, 379-383. [CrossRef] [PubMed]

124. Lyzenga, D.; Malinas, N.; Tanis, F. Multispectral bathymetry using a simple physically based algorithm. IEEE Trans. Geosci. Remote Sens. 2006, 44, 2251-2259. [CrossRef]

125. Stumpf, R.P.; Holderied, K.; Sinclair, M. Determination of water depth with high-resolution satellite imagery over variable bottom types. Limnol. Oceanogr. 2003, 48, 547-556. [CrossRef]

126. Dekker, A.G.; Phinn, S.R.; Anstee, J.; Bissett, P.; Brando, V.E.; Casey, B.; Fearns, P.; Hedley, J.; Klonowski, W.; Lee, Z.P.; et al. Intercomparison of shallow water bathymetry, hydro-optics, and benthos mapping techniques in Australian and Caribbean coastal environments. Limnol. Oceanogr. Methods 2011, 9, 396-425. [CrossRef]

127. Mobley, C.D.; Sundman, L.K.; Davis, C.; Bowles, J.H.; Downes, T.V.; Leathers, R.A.; Montes, M.J.; Bissett, W.P.; Kohler, D.D.R.; Reid, R.P.; et al. Interpretation of hyperspectral remote-sensing imagery by spectrum matching and look-up tables. Appl. Opt. 2005, 44, 3576-3592. [CrossRef] [PubMed]

128. Klonowski, W.M.; Fearns, P.R.C.S.; Lynch, M.J. Retrieving key benthic cover types and bathymetry from hyperspectral imagery. J. Appl. Remote Sens. 2007, 1, 011505. [CrossRef]

129. Brando, V.E.; Anstee, J.M.; Wettle, M.; Dekker, A.G.; Phinn, S.R.; Roelfsema, C. A physics based retrieval and quality assessment of bathymetry from suboptimal hyperspectral data. Remote Sens. Environ. 2009, 113, 755-770. [CrossRef]

130. Lee, Z.; Carder, K.L.; Mobley, C.D.; Steward, R.G.; Patch, J.S. Hyperspectral remote sensing for shallow waters. I. A semianalytical model. Appl. Opt. 1998, 37, 6329-6338. [CrossRef] [PubMed]

131. Lee, Z.; Carder, K.L.; Mobley, C.D.; Steward, R.G.; Patch, J.S. Hyperspectral remote sensing for shallow waters: 2. Deriving bottom depths and water properties by optimization. Appl. Opt. 1999, 38, 3831-3843. [CrossRef] [PubMed]

132. Mobley, C.D.; Sundman, L. Hydrolight 4.1 User's Guide. Sequoia Scientific, 2000. Available online: http://www.sequoiasci.com/products/Hydrolight.aspx (accessed on 25 January 2016). 
133. Lesser, M.P.; Mobley, C.D. Bathymetry, water optical properties, and benthic classification of coral reefs using hyperspectral remote sensing imagery. Coral Reefs 2007, 26, 819-829. [CrossRef]

134. Vahtmäe, E.; Kutser, T. Classifying the Baltic Sea shallow water habitats using image based and spectral library methods. Remote Sens. 2013, 5, 2451-2474. [CrossRef]

135. Hedley, J.D.; Roelfsema, C.; Phinn, S. Propagating uncertainty through a shallow water mapping algorithm based on radiative transfer model inversion. In Proceedings of the Ocean Optics XX, Anchorage, AK, USA, 27 September-1 October 2010.

136. Hedley, J.D.; Russell, B.; Randolph, K.; Dierssen, H. A physics-based method for the remote sensing of seagrasses. Remote Sens. Environ. 2015. [CrossRef]

137. Sanderson, E.W.; Jaiteh, M.; Levy, M.A.; Redford, K.H.; Wannebo, A.V.; Woolmer, G. The human footprint and the last of the wild. BioScience 2002, 52, 891-904. [CrossRef]

138. Bryant, D.; Burke, L.; McManus, J.; Spalding, M. Reefs at Risk: A Map-Based Indicator of Threats to the World's Coral Reefs; World Resources Institute: Washington, DC, USA, 1998; p. 56.

139. McField, M.; Kramer, P. Healthy Reefs for Healthy People. A Guide to Indicators of Reef Health and Social Well-Being in the Mesoamerican Reef Region; The Smithsonian Institution: Miami, FL, USA, 2007; p. 208.

140. Mumby, P.J.; Edwards, A.J.; Ernesto Arias-Gonzalez, J.; Lindeman, K.C.; Blackwell, P.G.; Gall, A.; Gorczynska, M.I.; Harborne, A.R.; Pescod, C.L.; Renken, H.; et al. Mangroves enhance the biomass of coral reef fish communities in the Caribbean. Nature 2004, 427, 533-536. [CrossRef] [PubMed]

141. Cihlar, J. Land cover mapping of large areas from satellites: Status and research priorities. Int. J. Remote Sens. 2000, 21, 1093-1114. [CrossRef]

142. Franklin, S.E.; Wulder, M.A. Remote sensing methods in medium spatial resolution satellite data land cover classification of large areas. Prog. Phys. Geogr. 2002, 26, 173-205. [CrossRef]

143. Gillanders, S.N.; Coops, N.C.; Wulder, M.A.; Gergel, S.E.; Nelson, T. Multitemporal remote sensing of landscape dynamics and pattern change: Describing natural and anthropogenic trends. Prog. Phys. Geogr. 2008, 32, 503-528. [CrossRef]

144. Lu, D.; Mausel, P.; Brondízio, E.; Moran, E. Change detection techniques. Int. J. Remote Sens. 2004, 25, 2365-2401. [CrossRef]

145. Loughland, R.A.; Saenger, P.; Luker, G.; Siddiqui, K.; Saji, B.; Belt, M.; Crawford, K. Changes in the coastal zone of Abu Dhabi determined using satellite imagery (1972-2003). Aquat. Ecosyst. Health Manag. 2007, 10, 301-308. [CrossRef]

146. Sesli, F.; Karsli, F.; Colkesen, I.; Akyol, N. Monitoring the changing position of coastlines using aerial and satellite image data: An example from the eastern coast of Trabzon, Turkey. Environ. Monit. Assess. 2009, 153, 391-403. [CrossRef] [PubMed]

147. Benfield, S.L.; Guzman, H.M.; Mair, J.M. Temporal mangrove dynamics in relation to coastal development in Pacific Panama. J. Environ. Manag. 2005, 76, 263-276. [CrossRef] [PubMed]

148. Kamal, M.; Phinn, S.; Johansen, K. Object-based approach for multi-scale mangrove composition mapping using multi-resolution image datasets. Remote Sens. 2015, 7, 4753-4783. [CrossRef]

149. Mumby, P.J. Connectivity of reef fish between mangroves and coral reefs: Algorithms for the design of marine reserves at seascape scales. Biol. Conserv. 2006, 128, 215-222. [CrossRef]

150. McCook, L.; Jompa, J.; Díaz-Pulido, G. Competition between corals and algae on coral reefs: A review of evidence and mechanisms. Coral Reefs 2001, 19, 400-417. [CrossRef]

151. Mumby, P.J. The impact of exploiting grazers (Scaridae) on the dynamics of Caribbean coral reefs. Ecol. Appl. 2006, 16, 747-769. [CrossRef]

152. Brewer, T.D.; Cinner, J.E.; Green, A.; Pandolfi, J.M. Thresholds and multiple scale interaction of environment, resource use, and market proximity on reef fishery resources in the Solomon Islands. Biol. Conserv. 2009, 142, 1797-1807. [CrossRef]

153. Cinner, J.E.; Graham, N.A.J.; Huchery, C.; MacNeil, M.A. Global effects of local human population density and distance to markets on the condition of coral reef fisheries. Conserv. Biol. 2013, 27, 453-458. [CrossRef] [PubMed]

154. Chollett, I.; Mumby, P.J. Predicting the distribution of Montastraea reefs using wave exposure. Coral Reefs 2012, 31, 493-503. [CrossRef]

155. Chollett, I.; Canty, S.W.J.; Box, S.J.; Mumby, P.J. Adapting to the impacts of global change on an artisanal coral reef fishery. Ecol Econ. 2014, 102, 118-125. [CrossRef] 
156. Elvidge, C.D.; Baugh, K.E.; Kihn, E.A.; Kroehl, H.W.; Davis, E.R.; Davis, C.W. Relation between satellite observed visible-near infrared emissions, population, economic activity and electric power consumption. Int. J. Remote Sens. 1997, 18, 1373-1379. [CrossRef]

157. Aubrecht, C.; Elvidge, C.D.; Longcore, T.; Rich, C.; Safran, J.; Strong, A.E.; Eakin, C.M.; Baugh, K.E.; Tuttle, B.T.; Howard, A.T.; et al. A global inventory of coral reef stressors based on satellite observed nighttime lights. Geocarto Int. 2008, 23, 467-479. [CrossRef]

158. Cinner, J.E.; McClanahan, T.R.; Daw, T.M.; Graham, N.A. J.; Maina, J.; Wilson, S.K.; Hughes, T.P. Linking social and ecological systems to sustain coral reef fisheries. Curr. Biol. 2009, 19, 206-212. [CrossRef] [PubMed]

159. Madin, E.M.P.; Madin, J.S.; Booth, D.J. Landscape of fear visible from space. Sci. Rep. 2011, 1, 14. [CrossRef] [PubMed]

160. Glynn, P.W.; D'Croz, L. Experimental evidence for high temperature stress as the cause of El Niño-coincident coral mortality. Coral Reefs 1990, 8, 181-191. [CrossRef]

161. Hoegh-Guldberg, O. Climate change, coral bleaching and the future of the world's coral reefs. Mar. Freshw. Res. 1999, 50, 839-866. [CrossRef]

162. Berkelmans, R. Time-integrated thermal bleaching thresholds of reefs and their variation on the Great Barrier Reef. Mar Ecol. Prog. Ser. 2002, 229, 73-82. [CrossRef]

163. Donner, S.D.; Skirving, W.J.; Little, C.M.; Oppenheimer, M.; Hoegh-Guldberg, O. Global assessment of coral bleaching and required rates of adaptation under climate change. Glob. Chang. Biol. 2005, 11, 2251-2265. [CrossRef]

164. Glynn, P.W. Coral bleaching and mortality in the tropical eastern Pacific during the 1982-83 E1 Nifio warming event. Mass Bleaching of Coral Reefs in the Caribbean: A Research Strategy; Research report 88-2; Ogden, J., Wicklund, R., Eds.; NOAA's Undersea Research Program: US Virgin Islands, USA, 1988; pp. 42-45.

165. Coffroth, M.A.; Lasker, H.R.; Oliver, J.K. Coral mortality outside of the eastern Pacific during 1982-1983: Relationship to El Niño. Elsevier Oceanogr. Ser. 1990, 52, 141-182.

166. Wilkinson, C.R. The 1997-1998 mass bleaching event around the world. Status of Coral Reefs of the World, 1998; Wilkinson, C.R., Ed.; Australian Institute of Marine Science: Cape Ferguson, Australia, 1998; pp. 15-38.

167. Wilkinson, C.; Souter, D. Status of Caribbean Coral Reefs After Bleaching and Hurricanes in 2005; Global Coral Reef Monitoring Network, and Reef and Rainforest Research Centre: Townsville, QLD, Australia, 2008; p. 152.

168. Thomas, C.R.; Heron, S.F. South-East Asia Coral Bleaching Rapid Response: Final Report; Commonwealth Scientific and Industrial Research Organisation, Wealth from Oceans Flagship: Canberra, Australia, 2011.

169. Moore, J.A.Y.; Bellchambers, L.M.; Depczynski, M.R.; Evans, R.D.; Evans, S.N.; Field, S.N.; Friedman, K.J.; Gilmour, J.P.; Holmes, T.H.; Middlebrook, R.; et al. Unprecedented mass bleaching and loss of coral across $12^{\circ}$ of latitude in Western Australia in 2010-11. PLoS ONE 2012, 7, e51807. [CrossRef] [PubMed]

170. Alemu, I.J.B.; Clement, Y. Mass coral bleaching in 2010 in the southern Caribbean. PLoS ONE 2014, 9, e83829.

171. Heron, S.F.; Liu, G.; Rauenzahn, J.L.; Christensen, T.R.L.; Skirving, W.J.; Burgess, T.F.R.; Eakin, C.M.; Morgan, J.A. Improvements to and continuity of operational global thermal stress monitoring for coral bleaching. J. Oper. Oceanogr. 2014, 7, 3-11. [CrossRef]

172. McWilliams, J.P.; Côté, I.M.; Gill, J.A.; Sutherland, W.J.; Watkinson, A.R. Accelerating impacts of temperature-induced coral bleaching in the Caribbean. Ecology 2005, 86, 2055-2060. [CrossRef]

173. Van Hooidonk, R.; Maynard, J.A.; Planes, S. Temporary refugia for coral reefs in a warming world. Nat. Clim. Chang. 2013. [CrossRef]

174. Winter, A.; Appeldoorn, R.S.; Bruckner, A.; Williams, E.H., Jr.; Goenaga, C. Sea surface temperatures and coral reef bleaching off La Parguera, Puerto Rico (northeastern Caribbean Sea). Coral Reefs 1998, 17, 377-382. [CrossRef]

175. Liu, G.; Rauenzahn, J.L.; Heron, S.F.; Eakin, C.M.; Skirving, W.J.; Christensen, T.R.L.; Strong, A.E.; Li, J. NOAA Coral Reef Watch $50 \mathrm{~km}$ Satellite Sea Surface Temperature-Based Decision Support System for Coral Bleaching Management; NOAA Technical Report NESDIS 143. NOAA/NESDIS: College Park, MD, USA, 2013; p. 33.

176. Montgomery, R.S.; Strong, A.E. Coral bleaching threatens oceans, life. Eos 1994, 75, 145-147. [CrossRef]

177. Gleeson, M.W.; Strong, A.E. Applying MCSST to coral reef bleaching. Adv. Space Res. 1995, 16, 151-154. [CrossRef]

178. Strong, A.E.; Barrientos, C.S.; Duda, C.; Sapper, J. Improved satellite techniques for monitoring coral reef bleaching. Proc. 8th Int. Coral Reef Symp. 1997, 8, 1495-1498. 
179. Goreau, T.; McClanahan, T.; Hayes, R.; Strong, A. Conservation of coral reefs after the 1998 global bleaching event. Conserv. Biol. 2000, 14, 5-15. [CrossRef]

180. Goreau, T.J.; Hayes, R.L. Coral bleaching and ocean hot-spots. Ambio-J. Hum. Environ. Res. Manag. 1994, 23, 176-180.

181. Atwood, D.K.; Hendee, J.C.; Mendez, A. An assessment of global warming stress on Caribbean coral reef ecosystems. Bull. Mar. Sci. 1992, 51, 118-130.

182. Skirving, W.J.; Strong, A.E.; Liu, G.; Liu, C.; Arzayus, F.; Sapper, J. Extreme events and perturbations of coastal ecosystems: Sea surface temperature change and coral bleaching. In Remote Sensing of Aquatic Coastal Ecosystem Processes; Richardson, L.L., LeDrew, E.F., Eds.; Springer: Dordrecht, the Netherlands, 2006; pp. 11-25.

183. Strong, A.E.; Arzayus, F.; Skirving, W.; Heron, S.F. Identifying coral bleaching remotely via Coral Reef Watch-Improved integration and implications for changing climate. In Coral Reefs and Climate Change: Science and Management. Coastal and Estuarine Studies; Phinney, J.T., Hoegh-Guldberg, O., Kleypas, J., Skirving, W., Strong, A., Eds.; American Geophysical Union: Washington, DC, USA, 2006; pp. 163-180.

184. Liu, G.; Heron, S.F.; Eakin, C.M.; Muller-Karger, F.E.; Vega-Rodriguez, M.; Guild, L.S.; De La Cour, J.L.; Geiger, E.F.; Skirving, W.J.; Burgess, T.F.R.; et al. Reef-scale thermal stress monitoring of coral ecosystems: New 5-km global products from NOAA Coral Reef Watch. Remote Sens. 2014, 6, 11579-11606. [CrossRef]

185. Heron, S.F.; Johnston, L.; Liu, G.; Geiger, E.F.; Maynard, J.A.; De La Cour, J.L.; Johnson, S.; Okano, R.; Benavente, D.; Burgess, T.F.R.; et al. Validation of Reef-Scale Thermal Stress Satellite Products for Coral Bleaching Monitoring. Remote Sens. 2016, 8. [CrossRef]

186. Maynard, J.A.; Turner, P.J.; Anthony, K.R.N.; Baird, A.H.; Berkelmans, R.; Eakin, C.M.; Johnson, J.; Marshall, P.A.; Packer, G.R.; Rea, A.; et al. ReefTemp: An interactive monitoring system for coral bleaching using high-resolution SST and improved stress predictors. Geophys. Res. Lett. 2008. [CrossRef]

187. Garde, L.A.; Spillman, C.M.; Heron, S.F.; Beeden, R. ReefTemp Next Generation: A new operational system for monitoring reef thermal stress. J. Oper. Oceanogr. 2014, 7, 21-33. [CrossRef]

188. Vega-Rodriquez, M.; Müller-Karger, F.E.; Hallock, P.; Quiles-Perez, G.A.; Eakin, C.M.; Colella, M.; Jones, D.L.; Li, J.; Soto, I.; Guild, L.; et al. Influence of water-temperature variability on stony coral diversity in Florida Keys patch reefs. MEPS 2015, 528, 173-186. [CrossRef]

189. Casey, K.S.; Brandon, T.B.; Cornillon, P.; Evans, R. The past, present and future of the AVHRR Pathfinder SST program. In Oceanography From SPACE: Revisited; Barale, V., Gower, J.F.R., Alberotanza, L., Eds.; Springer: Berlin, German, 2010; pp. 323-341.

190. Good, S.A.; Corlett, G.K.; Remedios, J.J.; Noyes, E.J.; Llewellyn-Jones, D.T. The global trend in sea surface temperature from 20 years of advanced very high resolution radiometer data. J. Climatol. 2007, 20, 1255-1264. [CrossRef]

191. Chollett, I.; Müller-Karger, F.E.; Heron, S.F.; Skirving, W.; Mumby, P.J. Seasonal and spatial heterogeneity of recent sea surface temperature trends in the Caribbean Sea and southeast Gulf of Mexico. Mar. Pollut. Bull. 2012, 64, 956-965. [CrossRef] [PubMed]

192. Peñaflor, E.; Skirving, W.; Strong, A.; Heron, S.; David, L. Sea-surface temperature and thermal stress in the Coral Triangle over the past two decades. Coral Reefs 2009, 28, 841-850. [CrossRef]

193. Selig, E.R.; Casey, K.S.; Bruno, J.F. New insights into global patterns of ocean temperature anomalies: Implications for coral reef health and management. Glob. Ecol. Biogeogr. 2010, 19, 397-411. [CrossRef]

194. Liu, G.; Matrosova, L.E.; Penland, C.; Gledhill, D.K.; Eakin, C.M.; Webb, R.S.; Christensen, T.R.L.; Heron, S.F.; Morgan, J.A.; Skirving, W.J.; Strong, A.E. NOAA Coral Reef Watch Coral Bleaching Outlook System. In Proceedings of the 11th International Coral Reef Symposium, Ft. Lauderdale, FL, USA, 7-11 July 2008; pp. 951-955.

195. Eakin, C.M.; Liu, G.; Chen, M.; Kumar, A. Ghost of bleaching future: Seasonal Outlooks from NOAA's Operational Climate Forecast System. In Proceedings of the 12th International Coral Reef Symposium, Cairns, Australia, 9-13 July 2012.

196. Spillman, C.M. Operational real-time seasonal forecasts for coral reef management. J. Oper. Oceanogr. 2011, 4, 13-22. [CrossRef]

197. Smith, L.W.; Birkeland, C. Effects of intermittent flow and irradiance level on back reef Porites corals at elevated seawater temperatures. J. Exp. Mar. Biol. Ecol. 2007, 341, 282-294. [CrossRef] 
198. Anthony, K.R.N.; Connolly, S.R.; Hoegh-Guldberg, O. Bleaching, energetics, and coral mortality risk: Effects of temperature, light, and sediment regime. Limnol. Oceanogr. 2007, 52, 716-726. [CrossRef]

199. Mumby, P.J.; Chisholm, J.R.M.; Edwards, A.J.; Andréfouët, S.; Jaubert, J. Cloudy weather may have saved Society Island reef corals during the 1998 ENSO event. Mar. Ecol. Prog. Ser. 2001, 222, 209-216. [CrossRef]

200. Nunez, M.; Hart, T.L.; Kalm, J.D. Estimating solar radiation in a tropical environment using satellite data. J. Climatol. 1984, 4, 573-585. [CrossRef]

201. Masiri, I.; Nunez, M.; Weller, E. A 10-year climatology of solar radiation for the Great Barrier Reef: Implications for recent mass coral bleaching events. Int. J. Remote Sens. 2008, 29, 4443-4462. [CrossRef]

202. Barnes, B.B.; Hallock, P.; Hu, C.; Muller-Karger, F.; Palandro, D.; Walter, C.; Zepp, R. Predition of coral bleaching in the Florida Keys using remotely sensed data. Coral Reefs 2015, 34, 491-503. [CrossRef]

203. Dunne, R.; Brown, B. The influence of solar radiation on bleaching of shallow water reef corals in the Andaman Sea, 1993-1998. Coral Reefs 2001, 20, 201-210.

204. Skirving, W.; Guinotte, J. The sea surface temperature story on the Great Barrier Reef during the coral bleaching event of 1998. In Oceanographic Processes of Coral Reefs. Physical and Biological Links in the Great Barrier Reef; Wolanski, E., Ed.; CRC Press: Bocan Raton, FL, USA, 2001; pp. 301-313.

205. Obura, D.O. Resilience and climate change: Lessons from coral reefs and bleaching in the Western Indian Ocean. Estuar. Coast. Shelf Sci. 2005, 63, 353-372. [CrossRef]

206. Heron, S.F.; Heron, M.L.; Pichel, W. Thermal and radar overview. In Coral Reef Remote Sensing: A Guide for Mapping, Monitoring and Management; Goodman, J.A., Phinn, S.R., Purkis, S.J., Eds.; Springer: Berlin, German, 2013; pp. 285-312.

207. Leigh, E.G.; Paine, R.T.; Quinn, J.F.; Suchanek, T.H. Wave energy and intertidal productivity. PNAS 1987, 84, 1314-1318. [CrossRef] [PubMed]

208. Barnes, D.J. Profiling coral reef productivity and calcification using $\mathrm{pH}$ and oxygen electrodes. J. Exp. Mar. Biol. Ecol. 1983, 66, 149-161. [CrossRef]

209. Roff, G.; Chollett, I.; Doropoulos, D.; Golbuu, Y.; Steneck, R.S.; Mumby, P.J. Exposure-driven phase shift following catastrophic disturbance on coral reefs. Coral Reefs 2015, 34, 715-725. [CrossRef]

210. Fulton, C.J.; Bellwood, D.R.; Wainwright, P.C. Wave energy and swimming performance shape coral reef fish assemblages. Proc. R. Soc. B-Biol. Sci. 2005, 272, 827-832. [CrossRef] [PubMed]

211. Ekebom, J.P.; Laihonen, T.; Suominen, T. A GIS-based step-wise procedure for assessing physical exposure in fragmented archipelagos. Estuar. Coast. Shelf Sci. 2003, 57, 887-898. [CrossRef]

212. Hamylton, S. The use of remote sensing and linear wave theory to model local wave energy around Alphonse Atoll, Seychelles. Estuar. Coast. Shelf Sci. 2011, 95, 349-358. [CrossRef]

213. Buckley, M.; Lowe., R.; Hansen, J. Evaluation of nearshore wave models in steep reef environments. Ocean Dyn. 2013, 64, 847-862. [CrossRef]

214. Phinn, S.R.; Dekker, A.G.; Brando, V.E.; Roelfsema, C.M. Mapping water quality and substrate cover in optically complex coastal and reef waters: An integrated approach. Mar. Pollut. Bull. 2005, 51, 459-469. [CrossRef] [PubMed]

215. Udy, J.; Gall, M.; Longstaff, B.; Moore, K.; Roelfsema, C.M.; Spooner, D.; Albert, S. Water quality monitoring: A combined approach to investigate gradients of change in the Great Barrier Reef, Australia. Mar. Pollut. Bull. 2005, 51, 224-238. [CrossRef] [PubMed]

216. Weeks, S.; Werdell, P.J.; Schaffelke, B.; Canto, M.; Lee, Z.; Wilding, J.G.; Feldman, G.C. satellite-derived photic depth on the Great Barrier Reef: Spatio-temporal patterns of water clarity. Remote Sens. 2012, 4, 3781-3795. [CrossRef]

217. IOCCG. Remote Sensing of Ocean Colour in Coastal and Other Optically-Complex Waters; Report No. 3; IOCCG: Dartmouth, NS, Canada, 2000.

218. Gordon, H.R. Atmospheric correction of ocean color imagery in the Earth Observing System Era. J. Geophys. Res. 1997, 102, 17081-17106. [CrossRef]

219. Moore, G.; Aiken, J.; Lavender, S. The atmospheric correction of water colour and the quantitative retrieval of suspended particulate matter in Case II waters: Application to MERIS. Int. J. Remote Sens. 1999, 20, 1713-1733. [CrossRef]

220. Hu, C.; Carder, K.L.; Müller-Karger, K.E. Atmospheric correction of SeaWiFS imagery over turbid coastal waters: A practical method. Remote Sens. Environ. 2000, 74, 195-206. [CrossRef] 
221. Cannizzaro, J.P.; Carder, K.L. Estimating chlorophyll a concentrations from remote-sensing reflectance in optically shallow waters. Remote Sens. Environ. 2006, 101, 13-24. [CrossRef]

222. Qin, Y.; Brando, V.E.; Dekker, A.G.; Blondeau-Patissier, D. Validity of SeaDAS water constituents retrieval algorithms in Australian tropical coastal waters. Geophys. Res. Lett. 2007, 34, L21603. [CrossRef]

223. McKinna, L.I.W.; Fearns, P.R.C.; Weeks, S.J.; Werdell, P.J.; Reichstetter, M.; Franz, B.A.; Shea, D.M.; Feldman, G.C. A semianalytical ocean color inversion algorithm with explicit water column depth and substrate reflectance parameterization. J. Geophys. Res. Oceans 2015, 120, 1741-1770. [CrossRef]

224. Doerffer, R.; Schiller, H. The MERIS Case 2 water algorithm. Int. J. Remote Sens. 2007, 28, 517-535. [CrossRef]

225. Lee, Z.; Carder, K.L. Effect of spectral band numbers on the retrieval of water column and bottom properties from ocean color data. Appl. Opt. 2002, 41, 2191-2201. [CrossRef] [PubMed]

226. Werdell, P.J.; Franz, B.A.; Bailey, S.W.; Feldman, G.C.; Vega-Rodriguez, M.; Guild, L.S.; De La Cour, J.L.; Boss, E.; Brando, V.E.; Dowell, M.; et al. Generalized ocean color inversion model for retrieving marine inherent optical properties. Appl. Opt. 2013, 52, 2019-2037. [CrossRef] [PubMed]

227. Barnes, B.B.; Hu, C.; Schaeffer, B.A.; Lee, Z.; Palandro, D.A.; Lehrter, J.C. MODIS-derived spatiotemporal water clarity patterns in optically shallow Florida Keys waters: A new approach to remove bottom contamination. Remote Sens. Environ. 2013, 134, 377-391. [CrossRef]

228. Brando, V.E.; Dekker, A.G.; Park, Y.J.; Schroeder, T. Adaptive semianalytical inversion of ocean color radiometry in optically complex waters. Appl. Opt. 2012, 51, 2808-2833. [CrossRef] [PubMed]

229. Tomlinson, M.C.; Stumpf, R.P.; Ransibrahmanakul, V.; Truby, E.W.; Kirkpatrick, G.J.; Pederson, B.A.; Vargo, G.A.; Heil, C.A. Evaluation of the use of SeaWiFS imagery for detecting Karenia brevis harmful algal blooms in the eastern Gulf of Mexico. Remote Sens. Environ. 2004, 91, 293-303. [CrossRef]

230. Segal, B.; Hevangelista, H.; Kampel, M.; Gonçalves, A.C.; Polito, P.S.; Santos, E.A. Potential impacts of polar fronts on sedimentation processes at Abrolhos Coral Reef (South-West Atlantic Ocean/Brazil). Cont. Shelf Res. 2008, 28, 533-544. [CrossRef]

231. Hu, C.; Müller-Karger, F.E.; Vargo, G.A.; Neely, M.B.; Johns, E. Linkages between coastal runoff and the Florida Keys ecosystem: A study of a dark plume event. Geophys. Res. Lett. 2004, 31, L15307. [CrossRef]

232. Otis, D.B.; Carder, K.L.; English, D.C.; Ivey, J.E. CDOM transport from the Bahamas Banks. Coral Reefs 2004, 23, 152-160. [CrossRef]

233. Paris, C.B.; Chérubin, L.M. River-reef connectivity in the Meso-American region. Coral Reefs 2008, $27,773-781$. [CrossRef]

234. Sheng, J.; Wang, L.; Andréfouët, S.; Hu, C.; Hatcher, B.G.; Müller-Karger, F.E.; Kjerfve, B.; Heyman, W.D.; Yang, B. Upper ocean response of the Mesoamerican barrier reef system to Hurricane Mitch and coastal freshwater inputs: A study using Sea-viewing Wide Field-of-view Sensor (SeaWiFS) ocean color data and a nested-grid ocean circulation model. J. Geophys. Res. 2007, 112, C07016. [CrossRef]

235. Soto, I.; Andréfouët, S.; Hu, C.; Müller-Karger, F.E.; Wall, C.C.; Sheng, J.; Hatcher, B.G. Physical connectivity in the Mesoamerican Barrier Reef System inferred from 9 years of ocean colour observations. Coral Reefs 2009, 28, 415-425. [CrossRef]

236. Andréfouët, S.; Mumby, P.J.; McField, M.; Hu, C.; Müller-Karger, F.E. Revisiting coral reef connectivity. Coral Reefs 2002, 21, 43-48. [CrossRef]

237. Fabricius, K.E.; De'ath, G.; Humphrey, C.; Zagorskis, I.; Schaffelke, B. Intra-annual variation in turbidity in response to terrestrial runoff on near-shore coral reefs of the Great Barrier Reef. Estuar. Coast. Shelf Sci. 2013, 116, 57-65. [CrossRef]

238. De'ath, G.; Fabricius, K. Water quality as a regional driver of coral biodiversity and macroalgae on the Great Barrier Reef. Ecol. Appl. 2010, 20, 840-850. [CrossRef] [PubMed]

239. Lee, Z.; Weidemann, A.; Kindlemann, J.; Arnone, R.; Carder, K.L.; Davis, C. Euphotic zone depth: Its derivation and implication to ocean-color remote sensing. J. Geophys. Res. 2007, 112, C03009. [CrossRef]

240. Lee, Z.P.; Shang, S.; Hu, C.; Du, K.; Weidemann, A.; Hou, W.; Lin, J.; Lin, G. Secchi disk depth: A new theory and mechanistic model for underwater visibility. Remote Sens. Environ. 2015, 169, 139-149. [CrossRef]

241. Zhao, J.; Barnes, B.; Melo, N.; English, D.; Lapointe, B.; Muller-Karger, F.; Schaeffer, B.; Hu, C. Assessment of satellite-derived diffuse attenuation coefficients and euphotic depths in south Florida coastal waters. Remote Sens. Environ. 2013, 131, 38-50. [CrossRef] 
242. Petus, C.; Collier, C.; Devlin, M.; Rasheed, M.; McKenna, S. Using MODIS data for understanding changes in seagrass meadow health: A case study in the Great Barrier Reef (Australia). Mar. Environ. Res. 2014, 98, 68-85. [CrossRef] [PubMed]

243. Wang, M.; Liu, X.; Jiang, L.; Son, S.; Sun, J.; Shi, W.; Tan, L.; Naik, P.; Mikelsons, K.; Wang, X.; et al. Evaluation of VIIRS ocean color products. Proc. SPIE 9261 Ocean Remote Sens. Monit. Space 2014. [CrossRef]

244. Wang, M.; Son, S.; Zhang, Y.; Shi, W. Remote sensing of water optical property for China's inland Lake Taihu using the SWIR atmospheric correction with 1640 and $2130 \mathrm{~nm}$ bands. IEEE J. Sel. Top. Appl. Earth Obs. Remote Sens. 2013, 6, 2505-2516. [CrossRef]

245. Wang, M.; Nim, C.J.; Son, S.; Shi, W. Characterization of turbidity in Florida's Lake Okeechobee and Caloosahatchee and St. Lucie estuaries using MODIS-Aqua measurements. Water Res. 2012, 46, 5410-5422. [CrossRef] [PubMed]

246. NASA. Pre-Aerosol, Clouds, and Ocean Ecosystem (PACE) Mission, Science Definition Team Report. NASA, Greenbelt, Md. 2012. Available online: http://decadal.gsfc.nasa.gov/pace.html (accessed on 25 January 2016).

247. Acker, J.G. The Color of the Atmosphere with the Ocean Below: A History of NASA'a Difficult Journey to Successful Biological Remote sensing of the Global Ocean; CreateSpace Independent Publishing Platform: Charleston, USA, 2015; p. 372.

248. Feely, R.A.; Sabine, C.L.; Lee, K.; Berelson, W.; Kleypas, J.; Fabry, V.J.; Millero, F.J. Impact of anthropogenic $\mathrm{CO}_{2}$ on the $\mathrm{CaCO}_{3}$ system in the oceans. Science 2004, 305, 362-366. [CrossRef] [PubMed]

249. Gattuso, J.-P.; Frankignoulle, M.; Bourge, I.; Romaine, S.; Buddemeier, R.W. Effect of calcium carbonate saturation of seawater on coral calcification. Glob. Planet Chang. 1998, 18, 37-46. [CrossRef]

250. Marubini, F.; Ferrier-Pages, C.; Cuif, J.-P. Suppression of growth in scleractinian corals by decreasing ambient carbonate ion concentration: A cross-family comparison. Proc. R. Soc. Lond. Ser. B 2002, 270, 179-184. [CrossRef] [PubMed]

251. Reynaud, S.; Leclercq, N.; Romaine-Lioud, S.; Ferrier-Pages, C.; Jaubert, J.; Gattuso, J.-P. Interacting effects of $\mathrm{CO}_{2}$ partial pressure and temperature on photosynthesis and calcification in a scleractinian coral. Glob. Chang. Biol. 2003, 9, 1660-1668. [CrossRef]

252. Langdon, C.; Atkinson, M.J. Effect of elevated $\mathrm{pCO}_{2}$ on photosynthesis and calcification of corals and interactions with seasonal change in temperature/irradiance and nutrient enrichment. J. Geophys. Res. 2005, 110, C09S07.

253. Leclercq, N.; Gattuso, J.-P.; Jaubert, J. $\mathrm{CO}_{2}$ partial pressure controls the calcification rate of a coral community. Glob. Chang. Biol. 2000, 6, 329-334. [CrossRef]

254. Lough, J.M. Coral calcification from skeletal records revisited. Mar. Ecol. Prog. Ser. 2008, 373, $257-264$. [CrossRef]

255. Cooper, T.F.; De' ath, G.; Fabricius, K.E.; Lough, J.M. Declining coral calcification in massive Porites in two nearshore regions of the northern Great Barrier Reef. Glob. Chang. Biol. 2008, 14, 529-538. [CrossRef]

256. Lough, J.M.; Devereux, M.J.; Barnes, D.J. Porites Coral Growth Records from the Arabian Gulf; Australian Institute of Marine Science: Townsville, Australian, 2003.

257. Kuffner, I.B.; Andersson, A.J.; Jokiel, P.L.; Rodgers, K.S.; Mackenzie, F.T. Decreased abundance of crustose coralline algae due to ocean acidification. Nat. Geosci. 2008, 1, 114-117. [CrossRef]

258. Jokiel, P.L.; Rodgers, K.S.; Kuffner, I.B.; Andersson, A.J.; Cox, E.F.; Mackenzie, F.T. Ocean acidification and calcifying reef organisms: A mesocosm investigation. Coral Reefs 2008, 27, 473-483. [CrossRef]

259. Havenhand, J.N.; Buttler, F.R.; Thorndyke, M.C.; Williamson, J.E. Near-future levels of ocean acidification reduce fertilization success in a sea urchin. Curr. Biol. 2008, 18, R651-R652. [CrossRef] [PubMed]

260. Anthony, K.R.N.; Kline, D.I.; Diaz-Pulido, G.; Dove, S.; Hoegh-Guldberg, O. Ocean acidification causes bleaching and productivity loss in coral reef builders. Proc. Natl. Acad. Sci. 2008, 105, 17442-17446. [CrossRef] [PubMed]

261. Van Hooidonk, R.; Maynard, J.A.; Manzello, D.; Planes, S. Opposite latitudinal gradients in projected ocean acidification and bleaching impacts on coral reefs. Glob. Chang. Biol. 2014, 20, 103-112. [CrossRef] [PubMed]

262. Orr, J.C.; Fabry, V.J.; Aumont, O.; Bopp, L.; Doney, S.C.; Feely, R.A.; Gnanadesikan, A.; Gruber, N.; Ishida, A.; Joos, F.; et al. Anthropogenic ocean acidification over the twenty-first century and its impact on calcifying organisms. Nature 2005, 437, 681-686. [CrossRef] [PubMed] 
263. Gledhill, D.K.; Wanninkhof, R.; Millero, F.J.; Eakin, M. Ocean acidification of the Greater Caribbean Region 1996-2006. J. Geophys. Res. 2008, 113, C10031. [CrossRef]

264. Parkinson, C.L.; Ward, A.; King, M.D. Earth Science Reference Handbook; National Aeronautics and Space Administration: Washington, DC, USA, 2006.

265. Turner, W.; Spector, S.; Gardiner, N.; Fladeland, M.; Sterling, E.; Steininger, M. Remote sensing for biodiversity science and conservation. Trends Ecol. Evol. 2003, 18, 306-314. [CrossRef]

266. Roberts, C.M.; Andelman, S.; Branch, G.; Bustamante, R.H.; Castilla, J.C.; Dugan, J.; Halpern, B.S.; Lafferty, K.D.; Leslie, H.; Lubchenco, J.; et al. Ecological criteria for evaluating candidate sites for marine reserves. Ecol. Appl. 2003, 13, S199-S214. [CrossRef]

267. Alevizon, W.; Richardson, R.; Pitts, P.; Serviss, G. Coral zonation and patterns of community structure in Bahamian reef fishes. Bull. Mar. Sci. 1985, 36, 304-318.

268. Mellin, C.; Parrott, L.; Andréfouët, S.; Bradshaw, C.J.A.; MacNeil, M.A.; Caley, M.J. Multi-scale marine biodiversity patterns inferred efficiently from habitat image processing. Ecol. Appl. 2012, 22, 792-803. [CrossRef] [PubMed]

269. Andréfouët, S.; Guzman, H.M. Coral reef distribution, status and geomorphology-biodiversity relationship in Kuna Yala (San Blas) archipelago, Caribbean Panama. Coral Reefs 2005, 24, 31-42. [CrossRef]

270. Lindsay, M.J.; Patterson, H.M.; Swearer, S.E. Habitat as a surrogate measure of reef fish diversity in the zoning of the Lord Howe Island Marine Park, Australia. Mar. Ecol. Prog. Ser. 2008, 353, 265-273. [CrossRef]

271. Dalleau, M.; Andréfouët, S.; Wabnitz, C.C.C.; Payri, C.; Wantiez, L.; Pichon, M.; Friedman, K.; Vigliola, L.; Benzoni, F. Use of habitats as surrogates of biodiversity for efficient coral reef conservation planning in Pacific Ocean islands. Conserv. Biol. 2010, 24, 541-552. [CrossRef] [PubMed]

272. Mumby, P.J.; Broad, K.; Brumbaugh, D.R.; Dahlgren, C.P.; Harborne, A.R.; Hastings, A.; Holmes, K.E.; Kappel, C.V.; Micheli, F.; Sanchirico, J.N. Coral reef habitats as surrogates of species, ecological functions, and ecosystem services. Conserv. Biol. 2008, 22, 941-951. [CrossRef] [PubMed]

273. Knudby, A.; Roelfsema, C.M.; Lyons, M.; Phinn, S.; Jupiter, S. Mapping fish community variables by integrating field and satellite data, object-based image analysis and modeling in a traditional Fijian fisheries management area. Remote Sens. 2011, 3, 460-483. [CrossRef]

274. Mellin, C.; Andréfouët, S.; Kulbicki, M.; Dalleau, M.; Vigliola, L. Remote sensing and fish-habitat relationships in coral reef ecosystems: Review and pathways for systematic multi-scale hierarchical research. Mar. Pollut. Bull. 2009, 58, 11-19. [CrossRef] [PubMed]

275. Pittman, S.J.; Christensen, J.D.; Caldow, C.; Menza, C.; Monaco, M.E. Predictive mapping of fish species richness across shallow-water seascapes in the Caribbean. Ecol. Model. 2007, 204, 9-21. [CrossRef]

276. Beger, M.; Possingham, H.P. Environmental factors that influence the distribution of coral reef fishes: Modeling occurrence data for broad-scale conservation and management. Mar. Ecol. Prog. Ser. 2008, 361, 1-13. [CrossRef]

277. Richards, B.L.; Williams, I.D.; Vetter, O.J.; Williams, G.J. Environmental factors affecting large-bodied coral reef fish assemblages in the Mariana Archipelago. PLoS ONE 2012, 7, e31374. [CrossRef] [PubMed]

278. Stoner, A.W. What constitutes essential nursery habitat for a marine species? A case study of habitat form and function for queen conch. Mar. Ecol. Prog. Ser. 2003, 257, 275-289. [CrossRef]

279. Harborne, A.R.; Mumby, P.J.; Kappel, C.V.; Dahlgren, C.P.; Micheli, F.; Holmes, K.E.; Brumbaugh, D.R. Tropical coastal habitats as surrogates of fish community structure, grazing, and fisheries value. Ecol. Appl. 2008, 18, 1689-1701. [CrossRef] [PubMed]

280. Ries, L.; Fletcher, R.J.; Battin, J.; Sisk, T.D. Ecological responses to habitat edges: Mechanisms, models, and variability explained. Annu. Rev. Ecol. Evol. Syst. 2004, 35, 491-522. [CrossRef]

281. Dorenbosch, M.; Grol, M.G.G.; Nagelkerken, I.; van der Velde, G. Distribution of coral reef fishes along a coral reef-seagrass gradient: Edge effects and habitat segregation. Mar. Ecol. Prog. Ser. 2005, 299, 277-288. [CrossRef]

282. Kleypas, J.A.; McManus, J.W.; Menez, L.A.B. Environmental limits to coral reef development: Where do we draw the line? Am. Zool. 1999, 39, 146-159. [CrossRef]

283. Renken, H.; Mumby, P.J.; Matsikis, I.; Edwards, H.J. Effects of physical environmental conditions on the patch dynamics of Dictyota pulchella and Lobophora variegata on Caribbean coral reefs. Mar. Ecol. Prog. Ser. 2010, 403, 67-73. [CrossRef] 
284. Chollett, I.; Mumby, P.J.; Müller-Karger, F.E.; Hu, C. Physical environments of the Caribbean Sea. Limnol. Oceanogr. 2012, 57, 1233-1244. [CrossRef]

285. Wang, M.; Ahmadia, G.; Chollett, I.; Huang, C.; Fox, H.; Wijonarno, A.; Madden, M. Delineating biophysical environments of the Sunda Banda Seascape, Indonesia. Int. J. Environ. Res. Public Health 2015, 12, 1069-1082. [CrossRef] [PubMed]

286. Spalding, M.D.; Fox, H.E.; Allen, G.R.; Davidson, N.; Ferdana, Z.A.; Finlayson, M.; Halpern, B.S.; Jorge, M.A.; Lombana, A.; Lourie, S.A.; et al. Marine ecoregions of the world: A bioregionalization of coastal and shelf areas. BioScience 2007, 57, 573-583. [CrossRef]

287. Pressey, R.L.; Cabeza, M.; Watts, M.E.; Cowling, R.M.; Wilson, K.A. Conservation planning in a changing world. TRENDS Ecol. Evol. 2007, 22, 583-592. [CrossRef] [PubMed]

288. De Araujo Barbosa, C.C.; Atkinson, P.M.; Dearing, J.A. Remote Sensing of ecosystem services: A systematic review. Ecol. Indic. 2015, 52, 430-443. [CrossRef]

289. Liquete, C.; Pirrodi, C.; Drakou, E.G.; Gurney, L.; Katsanevakis, S.; Charef, A.; Egoh, B. Current status and future prospects for the assessment of marine and coastal ecosystem services: A systematic review. PLoS ONE 2013, 8, e67737.

290. Arkema, K.K.; Verutes, G.M.; Wood, S.A.; Clarke-Samuels, C.; Rosado, S.; Canto, M.; Rosenthal, A.; Ruckelshaus, M.; Guannel, G.; Toft, J.; et al. Embedding ecosystem services in coastal planning leads to better outcomes for people and nature. PNAS 2015, 112, 7390-7395. [CrossRef] [PubMed]

291. Harborne, A.R.; Mumby, P.J.; Micheli, F.; Perry, C.T.; Dahlgren, C.P.; Holmes, K.E.; Brumbaugh, D.R. The functional value of Caribbean coral reef, seagrass and mangrove habitats to ecosystem processes. Adv. Mar. Biol. 2006, 50, 57-189. [PubMed]

292. Brock, J.C.; Yates, K.K.; Halley, R.B.; Kuffner, I.B.; Wright, C.W.; Hatcher, B.G. Northern Florida reef tract benthic metabolism scaled by remote sensing. Mar. Ecol. Progr. Ser. 2006, 312, 123-139. [CrossRef]

293. Perry, C.T.; Salter, M.A.; Harborne, A.R.; Crowley, S.F.; Jelks, H.L.; Wilson, R.W. Fish as major carbonate mud producers and missing components of the tropical carbonate factory. PNAS 2011, 108, 3865-3869. [CrossRef] [PubMed]

294. Mumby, P.J.; Wolff, N.H.; Bozec, Y.-M.; Chollett, I.; Halloran, P. Operationalizing the resilience of coral reefs in an era of climate change. Conserv. Lett. 2014, 7, 176-187. [CrossRef]

295. Halpern, B.S.; Walbridge, S.; Selkoe, K.A.; Kappel, C.V.; Micheli, F.; D'Agrosa, C.; Bruno, J.F.; Casey, K.S.; Ebert, C.; Fox, H.E.; et al. A global map of human impact on marine ecosystems. Science 2008, 319, 948-952. [CrossRef] [PubMed]

296. Game, E.T.; Watts, M.E.; Wooldridge, S.; Possingham, H.P. Planning for the resistance in marine reserves: A question of catastrophic importance. Ecol. Appl. 2008, 18, 670-680. [CrossRef] [PubMed]

297. Ban, N.C.; Pressey, R.L.; Weeks, S. Conservation objectives and sea-surface temperature anomalies in the Great Barrier Reef. Conserv. Biol. 2012, 26, 799-809. [CrossRef] [PubMed]

298. Mumby, P.J.; Elliott, I.A.; Eakin, C.M.; Skirving, W.; Paris, C.B.; Edwards, H.J.; Enriquez, S.; Igiesias-Prieto, R.; Cherubin, L.M.; Stevens, J.R. Reserve design for uncertain responses of coral reefs to climate change. Ecol. Lett. 2011, 14, 132-140.

299. Chollett, I.; Enriquez, S.; Mumby, P.J. Redefining thermal regimes to design reserves for coral reefs in the face of climate change. PLOS ONE 2014, 9, e110634. [CrossRef] [PubMed]

300. Levy, J.S.; Ban, N.C. A method for incorporating climate change modelling into marine conservation planning: An Indo-west Pacific example. Mar. Policy 2013, 38, 16-24. [CrossRef]

301. McLeod, E.; Moffitt, R.; Timmermann, A.; Salm, R.; Menviel, L.; Palmer, M.J. Warming seas in the coral triangle: Coral reef vulnerability and management implications. Coast. Manag. 2010, 38, 518-539. [CrossRef]

(C) 2016 by the authors; licensee MDPI, Basel, Switzerland. This article is an open access article distributed under the terms and conditions of the Creative Commons by Attribution (CC-BY) license (http://creativecommons.org/licenses/by/4.0/). 